\title{
Müzik Öğretmenliği Özel Yetenek Sınavlarına Başvuran Adayların Alan Puanları İle Sosyo-Demografik Özelliklerinin Karşılaştırılması
}

\author{
Hasan ARAPGİRLİOĞLU*
}

\author{
Kübra Dilek TANKIZ ${ }^{* *}$
}

Öz

Bu çalışmada Müzik Öğretmenliği yetenek sınavlarına başvuran adayların sınavdan elde ettikleri alan puanları (Müziksel İşitme-Yazma, Müziksel Söyleme, Müziksel Çalma) ile sosyo-demografik özellikleri arasındaki ilişkiler araştırılmıştır. Araştırma, tarama modellerinden biri olan ilişkisel tarama modeline göre desenlenmiştir. Çalışma 2010-2011 Eğitim Öğretim yılı özel yetenek sınavına başvuran 387 adayla gerçekleştirilmiştir. Adayların sosyo-demografik özellikteki bağımsız nitelik içeren özellikleri belirlenerek, elde ettikleri alan puanlarına ilişkin veriler öncelikle normal dağılım eğrilerine bakılarak şekilsel olarak taranmıştır. İkinci aşamada verilerin çarpıklık (Skewness) ve basıklık (Kurtosis) değerlerine bakılarak, Kolmogorov - Smirnov testleri uygulanmıştır. Çalışmanın sonucunda; cinsiyete, ailenin müzik ilgi durumuna, yaşantının çoğunun geçirildiği yere, çalgı alanına göre anlamlı bir fark bulunmamakla birlikte; Mezun olunan lise türüne, yetenek sınavlarına hazırlanma biçimlerine ve hazırlık süresine göre anlamlı farklılıkların olduğu saptanmıştır.

Anahtar Kelimeler: Müzik Yetenek Sınavı, Müzik Öğretmenliği Adayları, Müziksel Başarı, SosyoDemografi

\section{Comparison of Field Scores and Socio Demographic Traits of the Candidates of Music Teacher Training Programs'}

\section{Talent Examinations}

\begin{abstract}
In this study, correlations between the scores in the field of music (musical hearing, reading and writing examinations' scores) and socio-demographic traits of the entrants of Music Teacher Training Programs' talent examinations were investigated. The study was designed according to the paired samples model -being one of the survey models. It was carried out with 387 enrants of 2010-2011 talent examinations. Firstly, individual socio-demographic traits of the entrants which are independent in quality were determined. In the second phase, the data related to scores in the field music were examined graphically by checking out their bell shaped curves and KolmogorovSmirnov test results were also examined by checking out the Skewness and Kurtosis values of the data. At the end of the study, alongside the fact that there weren't any significant differences in terms of gender, the place where the entrants' lifetime were mostly spent, families' level of interest
\end{abstract}

\footnotetext{
* Prof. Dr., Kırıkkale Üniversitesi, Güzel Sanatlar Fakültesi, Müzik, h.arapgirlioglu@kku.edu.tr

** İnönü Üniversitesi, Eğitim Bilimleri Enstitüsü, dtankiz@hotmail.com
} 
in music, and the entrants' instruments; significant differences found related to the type of high school being graduated from, the way the entrants prepare for the exams and the lenght of the preparation period

Keywords: Talent Examinations In Music, Music Teacher Training Candidates, Musical Achievement, Socio-demography.

\section{GİRIŞ}

Türkiye'de mesleki müzik eğitimi veren çeşitli yükseköğretim programlarına öğrenci alımı özel yetenek sınavları ile yapılmaktadır. Özellikle yaz aylarında yapılan bu sınavlara; Türkiye'nin dört bir yanından, yaşantısının çoğunu büyükşehirlerde geçirmiş olanlardan kasabaköylerde geçirmiş olanlara kadar, farklı aile yapılarında yetişmiş, çeşitli liselerden mezun olan adaylar katılmaktadır. Bu açıdan sınavlara giren öğrencilerin sosyo-demografik özellikleri çeşitlilik göstermektedir.

$\mathrm{Bu}$ sınavlar ilgili bölüm ve anabilim dalları tarafından hazırlanan özel yetenek sınavları yönergesine ve ÖSYS kılavuzunda belirlenen esaslara göre uygulanmaktadır. Sınavların içeriği kurumların ölçmek istediği müziksel davranışlara göre farklılık gösterse de, temel yapı ve alt testlerin türleri bakımından çoğu programda benzerlik taşımaktadır. Müziksel İsitme, Müziksel Çalma ve Müziksel Söyleme Alanları her kurumda, özel yetenek sınavlarının temelini oluşturmakla birlikte, Müziksel Yazma ve Müziksel Okuma Alanları da ölçülmek istenen davranışlar doğrultusunda eklenebilmektedir. Araştırma kapsamında ele alınan 2010-2011 yılı İnönü Üniversitesi Eğitim Fakültesi Güzel Sanatlar Eğitimi Bölümü Müzik Öğretmenliği Programı Özel Yetenek Sınavları'nın müziksel alan boyutu üç bölüme ayrılmaktadır. Bu bölümler; Müziksel İşitmeYazma (MiY) Alanı (dikte, iki ses, üç ses, dört ses işitme, ezgi ve tartım yineleme), Müziksel Söyleme Alanı (şarkı söyleme-eser seslendirme) ve Müziksel Çalma Alanı (çalgı çalma) boyutlarından oluşmaktadır. Sınav, iki aşamalı bir yapıya sahiptir. Sınavın birinci aşamasını, Müziksel İşitme-Yazma Alanı; ikinci aşamasını ise Müziksel Çalma ve Müziksel Söyleme Alanları oluşturmaktadır (İnönü, 2010).
Bu sınavlar, öğrencilerin müziksel davranışları ne düzeyde gerçekleştirebileceklerine ilişkin hazırbulunuşluk düzeylerinin ölçüldüğü sınavlardır. Müziksel davranışların oldukça çeşitli ve karmaşık yapılar olduğunu belirten Boyle ve Radocy (1987: 86) bu davranışları dört ana başlık altında sınıflandırmıştır:

- Müziksel Performans Davranışları (Çalgı alanında veya Ses alanında)

- Müziksel Okuma ve Müziksel Yazma Davranışları

- Müzik Dinleme Davranışları

- Müzik İle İlgili Diğer Bilişsel Davranışlar (Tarih, Literatür, Müziksel Yapı vb.)

Müziksel davranışların, müziksel başarı ile sonuçlanabilmesi için önkoşul niteliği taşıyan, müziksel yetenek; bireyin müziğe yönelik eğitimsel bir süreçten geçmeden, müziksel davranışları yapabilmesine ilişkin doğuştan barındırdığı gizil güç olarak tanımlanabilir. Seashore (1915:1) müziksel yeteneği, kişiye doğuştan bahşedilen ve ancak küçük bir kısmı geliştirilebilecek olan doğanın bir hediyesi olarak görmektedir. Boyle ve Radocy (1987) ise müziksel yeteneğin varlığı için bilgi, beceri ve yaşantıya ihtiyaç olmadığını belirtmiştir. Müziksel yeteneğin temelini oluşturan yetenek kavramı ise; bilgi veya beceriyi öğrenebilmek için doğuştan sahip olunan gizilgücün yani kapasitenin, eğitim sonucu işlenerek yeni öğrenmeler için hazır hale getirilmiş şeklidir (Kuzgun, 2003:23).

Müziksel davranışların ölçülmesi amacı ile kullanılan müzik testlerini, Kwalwasser (1927) ve Colwell (1970) müziksel yetenek ve müziksel başarı boyutunda sınıflandırmıştır. Atak Yayla (2003) bu alanlara ek olarak, müzik beğenisi boyutunu da eklemiştir. Boyle ve Radocy (1987) ise müziksel yetenek ve müziksel başarı boyutuna ek olarak; müziksel performans ile 
müziksel tutum ve diğer duygusal değişkenleri içeren testleri de bu sinfflandırmaya dahil etmiştir. Bu sınıflandırmalar dikkate alındığında, Türkiye'de, müzik öğretmenliği programlarında uygulanan testler; salt yeteneğin ölçüldüğü, özellikle devinimsel ve duyumsal becerileri ölçmeyi amaçlayan testler kapsamında yer almadığı için müziksel yetenek testlerinden ziyade müziksel başarı testleri olarak düşünülebilir. Çünkü Müziksel başarı, müziksel yeteneğin öğrenme yaşantılarıla harmanlanmasının bir sonucudur.

Müzik testlerine ilişkin yapılan sınıflandırmalardan yararlanılarak, dünyada yaygin olarak kullanılan standartlaştırılmış müzik testleri; müziksel yetenek testleri ve müziksel başarı testleri olarak gruplandırılmıştır. $\mathrm{Bu}$ örneklerden bazıları şunlardır:

- Müziksel Yetenek Testleri:

Seashore Müziksel Yetenek Testi, Wing Standartlaştırılmış Müziksel Zeka Testleri, Bentley Müziksel Yetenekler Testleri, Gordon MAP, Gordon PIMMA, Gordon IMMA, Gordon AMMA, K-D Müzik Testleri, Kwalwasser Müzik Yeteneği Testi, Drake Müziksel Yetenek Testleri, Gaston Müzikalite Testi, Biondo Müzik Yeteneği Testi, Leblanc Müzik Yeteneği Sınavı, Müzik Dinlemeyi Değerlendirme Formu, TilsonGretsch Müziksel Yetenek Testleri, PanAmerikan Music Aptitude Test

- Müziksel Başarı Testleri:

Müzik Başarısı Testleri, Iowa Müziksel Okuma Testleri, Silver Burdett Müziksel Yetenek Testleri, Knuth Müzik Başarısı Testleri, Beach Standartlaştırılmış Müzik Testleri, TogersonFahnestock Müzik Testi, Aliferis Müzik Başarısı Testi, Aliferis-Stecklein Müzik Başarısı Testi, Kwalwasser-Ruch Müziksel Başarı Testi, Kwalwasser Müzik Bilgisi ve Beğenisi Testi, Watkins-Farnum Performans Ölçeği, Mosher Bireysel Söyleme Testi, Hillbrand Deşifre Testi (Atak Yayla, 2003; Bentley, 1966; Boyle ve Radocy, 1987; Gordon 1979, 1986; Colwell, 1970; Kwalwasser, 1927; Moos, 1933; Roby, 1962;
Togerson ve Fahnestock, 1926; Warnick, 1985; Wing, 1970; Woodruff, 1983)

Yapılan sınavların ana kaynağının öğrenci olduğu düşünüldüğünde; özel yetenek sınavı ile öğrenci alımı yapan müzik öğretmenliği programına başvuran öğrencilerin sosyodemografik özelliklerinin incelenmesi, ilgili kurumlarda verilen eğitimin niteliğini geliştirmek açısından önemli rol oynamaktadır. $\mathrm{Bu}$ seçme sınavları bünyesinde yer alan müzik alanı puanları ile adayların kişisel özellikleri arasında ilişki olup olmadığı konusu, üzerinde durulması gereken bir noktadır. Adayların sosyo-demografik özellikleri ile müzik alanı puanları arasında nasıl bir ilişki olduğu araştırmanın temel problem durumu olarak görülmüştür.

$\mathrm{Bu}$ düşünceler doğrultusunda araştırmanın problemi şu şekilde ortaya çıkmaktadır; Özel yetenek sınavlarına başvuran adayların yetenek sinavindan elde ettikleri alan puanları ile sosyodemografik özellikleri arasındaki ilişkiler ne düzeydedir? biçiminde oluşturulmuştur.

Bu araştırmada müzik alanı puanları ile sosyodemografik özellikler arasındaki ilişki durumu incelenmiştir. Adayların cinsiyet, yaş, mezun olunan lise türü, yaşantının çoğunun geçirildiği yer ve bölge, aile müzik ilgi durumu, anne-baba eğitim durumu, aile aylık gelir durumu, hazırlık süresi ve hazırlanma biçimi, hazırlık süresi dışında müzik eğitimi alma durumu, puanların çalgı alanlarına göre farklılaşma durumu gibi sosyo-demografik özellikleri ile müzik alanı puanlarının tespit edilmesinin amaçlandığı bu çalışmanın alt problemleri aşağıda verilmiştir:

- Özel yetenek sinavina giren adayların; cinsiyet, yaş, mezun olunan lise türü ve yaşantının geçirildiği yer-bölge, anne-baba eğitim durumları ve aile aylık gelir (varsa kendisininki de dahil) durumu, bağımsız değişkenlerine göre frekans ve yüzde dağılımları nasıldır?

- Özel yetenek sınavına giren adayların çeşitli değişkenlere göre;

Müziksel İşitme-Yazma (MIY) Alanı puanları, 
Müziksel Çalma Alanı puanları,

Müziksel Söyleme Alanı puanları, anlamlı farklılık göstermekte midir?

Araştırma; müzik öğretmenliği programı özel yetenek sınavlarına başvuran adayların Müziksel İşitme-Yazma, Müziksel Söyleme ve Müziksel Çalma durumlarını ortaya koyması, adayların özel yetenek sınavında aldıkları alan puanları ile sosyo-demografik değişkenleri arasındaki ilişkiler hakkında fikir vermesi bakımından önem taşımaktadır. Araştırmanın; müzik eğitimcilerini, öğrenci adaylarını ve ailelerini, araştırmacıları ve ilgili makamları aydınlatması, daha sonraki çalışmalara ışık tutması açısından da yarar sağlayacağı düşünülmektedir.

\section{YÖNTEM}

Araştırma, Müzik Öğretmenliği özel yetenek sınavlarına başvuran adayların sinavdan elde ettikleri müziksel boyuta ilişkin alan puanları (MIYY, Müziksel Söyleme, Müziksel Çalma) ile sosyo-demografik özellikleri arasındaki ilişkisel durumu ortaya koyması bakımından ilişkisel tarama modeline göre desenlenmiştir. Karasar (2007) ilişkisel tarama modellerini, evren hakkında genel bir yargiya varmak amacı ile birden fazla değişken arasındaki ilişki durumunu ve düzeyini tespit etmek üzere yapılan araştırma modelleri olarak tanımlamışıı.
Araştırmanın çalışma grubunu 2010-2011 yılı İnönü Üniversitesi Eğitim Fakültesi Güzel Sanatlar Eğitimi Bölümü Müzik Öğretmenliği Programı Özel Yetenek Sinavina giren 387 aday oluşturmaktadır.

Araştırmada veri toplama araçlarını; araştırmacı tarafından oluşturulan "Kişisel Bilgi Formu" ve adayların sinavda aldıkları puanlar oluşturmaktadır. Adayların özel yetenek sinavından aldıkları puanlara, İnönü Üniversitesi Eğitim Fakültesi Dekanlığı'nın ilgili biriminden ulaşılmıştır (İnönü Üniversitesi, 2010).

Verilerin istatistiksel olarak incelenmesi amacı ile elde edilen tüm veriler, istatistiksel işlemlerin yapılmasında kullanılan SPSS 16.0 programına işlenmiştir. Öncelikle çalışma evrenini oluşturan adayların özelliklerine ilişkin istatistikler, yüzde ve frekans değerleri verilerek sunulmuştur.

İkinci aşamada verilerin çarpıklık (skewness) ve basıklık (kurtosis) değerlerine de bakılarak, Kolmogorov-Smirnov testi sonuçları incelenmiştir. $\mathrm{Bu}$ testin uygulanması, verilerin grup büyüklüğünün 50 'den fazla olması durumunda yapılan yöntemlerden biridir (Büyüköztürk, 2007: 42). Puanların dağılımının normallikten aşırı sapma gösterip göstermediği incelenmiştir. Dört puan türünün KolmogorovSmirnov testi sonuçları Tablo 1'de verilmiştir.

Tablo.1. Puanların çarpıklık-basıklık Değerleri ve Kolmogorov-Smirnov Testi Anlamlılık Düzeyi Sonuçları

\begin{tabular}{lcccc}
\hline & $\mathrm{n}$ & Çarpıklık & Basıklık & $\mathrm{p}$ \\
\hline Müziksel İșitme-Yazma Alanı P. & 387 & .361 & -.629 & .000 \\
Müziksel İşitme-Yazma Alanı P.* & 65 & .977 & .510 & .001 \\
Müziksel Çalma Alanı P. & 65 & .257 & -1.184 & .022 \\
Müziksel Söyleme Alanı P. & 65 & .473 & -.498 & .065 \\
\hline
\end{tabular}

*Sadece ikinci aşama sınavına giren adayların puanları

Tablo 1'deki Kolmogorov-Smirnov testi anlamlılık düzeyi sonuçları incelendiğinde, adayların Müziksel Söyleme Alanı puanları (p>.05)dışındaki diğer puan türlerinin normal dağılım göstermedikleri belirlenmiştir. Bu aşamadan sonra araştırmada kullanılan tüm puanların çarpıklık değerlerine bakılmıştır. Bir veri grubuna ilişkin puanların çarpıklık değerinin $+1,-1$ aralığında olmasının normal dağılım için kabul edilebilir düzeyde olmasının yanı sıra, bu değerin $+2,-2$ aralığında olması da genellikle kabul edilebilir bir durum olarak görülmektedir (Cooper Cutting, 2010). Bu bağlamda, çarpıklık katsayılarına bakıldığında, bütün değerlerin +2 , -2 aralığında olduğu ve puanların dağılımında aşırı bir sapma olmadığı görülmektedir.

Adayların sosyo-demografik özelliklerine yani bağımsız değişkenlere MiY Alanı, Müziksel Çalma Alanı, Müziksel Söyleme Alanı puanları arasında anlamlı fark olup olmadığına 
bakılmıştır. Her ne kadar üç puan türünde normal dağılımdan aşırı sapmalar olmadığı tespit edilse de, bağımsız değişken gruplarına göre puanlarda anlamlı fark olup olmadığının incelendiği küçük gruplarda, yani dağılımın homojen olmadiğı durumlarda $(N<30))$ parametrik olmayan alternatif testler kullanılmıştır. Büyüköztürk, Bökeoğlu ve Köklü (2009:63) bu durumu "pek çok özelliğin evrende normal bir dağılım göstermesine karşılık, ilgilenilen bir özelliğe ilişkin ölçümlerin küçük bir gruptan elde edilmesi durumunda $(\mathrm{N}<30)$, normal dağılımdan sapmalar olacaktır" şeklinde açıklamıştır. $\mathrm{Bu}$ bağlamda, cinsiyete göre, dağılımın normal olduğu durumlarda $t$-testi ve dağılımın homojen olmadığı durumlarda MannWhitney $U$ testi uygulanmıştır. Diğer değişkenlere göre gruplardaki dağıllımın normal olduğu durumlarda tek yönlü varyans analizi (ANOVA) uygulanmış, anlamlı farklılıkların hangi gruplar arasında olduğunu belirlemek için Tukey testi kullanılmıştır. Dağılımın normal olmadığ 1 durumlarda ise Kruskal-Wallis $\mathrm{H}$ testi uygulanmıştır. Farkların hangi gruplar

Tablo 2. Adayların Cinsiyet, Yaş, Lise Türü, Yaşantının Çoğunun Geçirildiği Yer-Bölge Değişkenlerine Göre Dağılımları

\begin{tabular}{|c|c|c|c|}
\hline \multicolumn{4}{|c|}{ Göre Dağılımları } \\
\hline & & $\mathrm{f}$ & $\%$ \\
\hline \multirow{2}{*}{ Cinsiyet } & $\mathrm{K}_{1 \mathrm{Z}}$ & 178 & 46.0 \\
\hline & Erkek & 209 & 54.0 \\
\hline \multirow{3}{*}{ Yaş } & $17-20$ & 289 & 74.7 \\
\hline & $21-24$ & 81 & 21.0 \\
\hline & 25 ve üstü & 17 & 4.3 \\
\hline \multirow{7}{*}{ Mezun Olunan Lise Türü } & GSSL & 188 & 48.6 \\
\hline & Genel Lise & 160 & 41.3 \\
\hline & Anadolu Lisesi & 10 & 2.6 \\
\hline & Meslek Lisesi & 13 & 3.4 \\
\hline & Açık Öğretim Lisesi & 10 & 2.6 \\
\hline & Yabancı Dil Ağırlıklı Lise & 5 & 1.3 \\
\hline & Özel Lise & 1 & 0.3 \\
\hline \multirow{5}{*}{ Yaşantının Çoğunun Geçirildiği Yer } & Büyükșehir & 98 & 25.3 \\
\hline & İl & 207 & 53.5 \\
\hline & İlçe & 52 & 13.4 \\
\hline & Kasaba & 10 & 2.6 \\
\hline & Köy & 20 & 5.2 \\
\hline \multirow{7}{*}{ Yaşantının Çoğunun Geçirildiği Bölge } & Akdeniz & 74 & 19.1 \\
\hline & Ege & 4 & 1.1 \\
\hline & Marmara & 11 & 2.8 \\
\hline & Doğu Anadolu & 123 & 31.8 \\
\hline & Güneydoğu Anadolu & 90 & 23.3 \\
\hline & Karadeniz & 23 & 5.9 \\
\hline & İç Anadolu & 62 & 16.0 \\
\hline
\end{tabular}

arasındaki olduğunu belirlemek için grupların ikili kombinasyonları üzerinden Mann-Whitney $\mathrm{U}$ testi uygulanmış, elde edilen veriler açıklanmıştır. Anlamlılık düzeyi (p) .05 olarak alınmıştır. Tukey testi ile Kruskal-Wallis H testinden sonra uygulanan Mann-Whitney U testi sonuçları tabloların altında verilmiş, diğer test sonuçları ise tablolaştırılarak yorumlanmıştır.

\section{BULGULAR}

Araştırmadan elde edilen bulgular, araştırmanın alt amaçları doğrultusunda ele alınmıştır.

3.1. Adayların; Cinsiyet, Yaş, Mezun Olunan Lise Türü Ve Yaşantının Geçirildiği Yer-Bölge, Anne-Baba Eğitim Durumları ve Aile Aylık Gelir Durumu, Bağımsız Değişkenlerine İlişkin Bulgular

Adayların; cinsiyet, yaş, mezun olunan lise türü ve yaşantının geçirildiği yer-bölge bağımsız değişkenlerine göre frekans ve yüzde dağılımları Tablo 2' de verilmiştir. 
Tablo 2 incelendiğinde, sinava giren adayların \%54'ünün erkek, \%46'sının ise k1z olduğu görülmektedir. Yaş dağılımına bakıldığında, adayların \%74.7'sinin 17-20 yaş aralığında, \%21'inin 21-24 yaş aralığında , \%4.3'ünün ise 25 ve üstü yaş aralığında oldukları belirlenmiştir. Yı̆̆ılmanın 17-20 yaş aralığında olduğu gözlemlenmektedir. Adayların \%48.6'sının GSSL(Güzel Sanatlar ve Spor Lisesi), \%41.3'ünün genel lise, \%3.4'ünün meslek lisesi, \%2.6'sının açık öğretim lisesi, yine \%2.6'sının Anadolu lisesi ve \%1.3'ünün yabancı dil ağırlıklı lise mezunu olduğu görülmektedir. GSSL ve genel lise mezunu adayların çoğunlukta oldukları saptanmıştır. Yaşantının çoğunun geçirildiği yer dağılımına bakıldığında, adayların \%53.5'inin il, \%25.3'ünün büyükşehir, \%13.4'ünün ilçe, \%5.2'sinin köy, \%2.6'sının kasaba grubunda oldukları belirlenmiştir. Yaşantılarının çoğunu il ve büyükşehirlerde geçirenlerin çoğunlukta oldukları gözlemlenmektedir. Adayların \%31.8'i Doğu Anadolu Bölgesi, \%23.3'ü Güneydoğu Anadolu Bölgesi, \%19.1'i Akdeniz Bölgesi, \%5.9'u Karadeniz Bölgesi, \%2.8'i Marmara Bölgesi, \%1.1'i ise Ege Bölgesinde yaşantılarının çoğunu geçirmişlerdir. Diğer gruplara göre yaşantılarının çoğunu Doğu Anadolu Bölgesinde geçirenler daha fazladır.

Adayların; anne-baba eğitim durumları ve aile aylık gelir (varsa kendisininki de dahil) durumu bağımsız değişkenlerine göre adayların frekans ve yüzde dağılımları Tablo 3'te verilmiştir.

Tablo 3. Adayların Anne-Baba Eğitim Durumları ve Aile Aylık Gelir Durumuna Göre Dağılımları

\begin{tabular}{|c|c|c|c|}
\hline & & $\mathrm{f}$ & $\%$ \\
\hline \multirow{5}{*}{ Anne Eğitim Durumu } & Okuryazar Olmayan & 36 & 9.3 \\
\hline & İlköğretim & 196 & 50.6 \\
\hline & Lise & 110 & 28.4 \\
\hline & Üniversite & 44 & 11.4 \\
\hline & Lisansüstü & 1 & 0.3 \\
\hline \multirow{5}{*}{ Baba Eğitim Durumu } & Okuryazar Olmayan & 4 & 1.0 \\
\hline & İlköğretim & 145 & 37.5 \\
\hline & Lise & 152 & 39.3 \\
\hline & Üniversite & 82 & 21.2 \\
\hline & Lisansüstü & 4 & 1.0 \\
\hline \multirow{7}{*}{ Aile Aylık Gelir } & $0-499$ & 34 & 8.8 \\
\hline & $500-999$ & 113 & 29.2 \\
\hline & $1000-1499$ & 113 & 29.2 \\
\hline & $1500-1999$ & 82 & 21.1 \\
\hline & $2000-2499$ & 18 & 4.7 \\
\hline & 2500-2999 & 12 & 3.1 \\
\hline & 3000 ve üstü & 15 & 3.9 \\
\hline
\end{tabular}

Tablo 3'e bakıldı̆̆ında, adayların annelerinin \%50.6'sının ilköğretim, \%28.4'ünün lise, \%11.4'ünün üniversite, \%0.3'ünün lisansüstü mezunu olduğu ve \%9.3'ünün ise okuryazar olmadığı belirlenmiştir. Yı̆̆ılmanın anne eğitim durumu ilköğretim ve lise olan adaylarda olduğu görülmektedir. Adayların baba eğitim durumu incelendiğinde, \%39.3'ünün lise, \%37.5'inin ilköğretim, \%21.2'sinin üniversite, $\% 1$ 'inin lisansüstü düzeyinde olduğu, \%1'inin ise okuryazar olmadığı tespit edilmiştir. Babaları lise ve ilköğretim mezunu olan adayların, diğer gruplardan daha fazla oldukları görülmektedir. Adayların aile aylık gelir (varsa kendisininki de dahil) durumlarına bakıldığında, 500-999 TL grubunda olanların \%29.2 oranında, 1000-1499 TL grubunda olanların yine \%29.2 oranında, 1500-1999 TL grubunda olanlarin \%21.1 oranında, 0-499 TL grubunda olanların \%8.8 oranında, 2000-2499 TL grubunda olanların \%4.7 oranında, $3000 \mathrm{TL}$ ve üstü grubunda olanların \%3.9 oranında, 2500-2999 TL grubunda olanların ise \%3.1 oranında oldukları belirlenmiştir. 500999 TL ve 1000-1499 TL grubunda olanlarin, 
diğer gruplardan daha fazla oldukları görülmektedir. Yı̆̆ılmanın ise 500-1499 TL aralığında olduğu gözlemlenmektedir.

3.2. Çeşitli Değişkenler ile Müziksel İşitmeYazma (MİY) Alanı, Müziksel Çalma Alanı, Müziksel Söyleme Alanı ve Yerleştirme Puanları Arasındaki İlişkilere Yönelik Bulgular
3.2.1. Çeşitli Değişkenler ile Müziksel İşitmeYazma Alanı Puanları Arasındaki İlișkilere Yönelik Bulgular

Adayların cinsiyete göre MIY Alanı puanlarının t-testi sonuçları Tablo 4'te yer almaktadır.

Tablo 4. MiY Alanı Puanlarının Cinsiyete Göre t-testi Sonuçları

\begin{tabular}{lcccccc}
\hline Cinsiyet & $\mathrm{N}$ & $\bar{X}$ & $\mathrm{~S}$ & $\mathrm{sd}$ & $t$ & $\mathrm{p}$ \\
\hline Kız & 178 & 34.68 & 17.27 & 385 & .265 & .791 \\
Erkek & 209 & 34.19 & 18.74 & & \\
\hline Tablo 4'deki $t$-testi sonuçlarına göre kız adaylar ( & Adayların mezun olunan lise türüne göre MiYY \\
$\bar{X}=34.68)$ ile erkek adaylar $(\bar{X}=34.19)$ arasında & Alanı puanlarının tek yönlü varyans analizi \\
MiY puanlarında $(t=.265$, p $>.05)$ anlamlı fark & sonuçları (ANOVA) Tablo 5'te yer almaktadır.
\end{tabular}
olmadığı görülmektedir.

Tablo 5. MIYY Alanı Puanlarının Mezun Olunan Lise Türüne Göre Tek Yönlü Varyans Analizi Sonuçları (ANOVA)

\begin{tabular}{lccccc}
\hline Varyansın Kaynağı & Kareler Toplamı & sd & Kareler Ortalaması & $\mathrm{f}$ & $\mathrm{p}$ \\
\hline Gruplararası & 13565,416 & 2 & 6782,708 & 23,174 & .000 \\
Gruplariçi & 112389,491 & 384 & 292,681 & & \\
Toplam & 125954,907 & 386 & & & \\
\hline
\end{tabular}

Tablo 5'deki varyans analizi sonuçlarına göre, MiY Alanı puanları mezun olunan lise türü gruplarına göre anlamlı bir farklılık göstermektedir $(\mathrm{F}(2,384)=23,17, \mathrm{p}<.01)$. Farkların hangi gruplar arasında olduğunu belirlemek amacı ile yapılan Tukey testinin sonuçlarına göre, GSSL mezunu adayların puanlarının ( $\bar{X}$ $=40.49)$; genel lise $(\bar{X}=28.43)$ ve diğer lise $(\bar{X}$ =29,64) türlerinden mezun olan adayların puanlarına göre anlamlı bir farklılık gösterdiği, GSSL mezunlarının MIYY Alanı puanlarının daha yüksek olduğu gözlenmektedir.

Adayların yaşantının çoğunun geçirildiği yere göre, MIYY Alanı puanlarının tek yönlü varyans analizi sonuçları (ANOVA) Tablo 6'da yer almaktadir.

Tablo 6. MiYY Alanı Puanlarının Yaşantının Çoğunun Geçirildiği Yere Göre Tek Yönlü Varyans Analizi Sonuçları (ANOVA)

\begin{tabular}{lccccc}
\hline Varyansın Kaynağı & Kareler Toplamı & $\mathrm{sd}$ & Kareler Ortalaması & $\mathrm{f}$ & $\mathrm{p}$ \\
\hline Gruplararası & 6108,523 & 3 & 2036,174 & 6,507 & .000 \\
Gruplariçi & 119846,384 & 383 & 312,915 & & \\
Toplam & 125954,907 & 386 & & & \\
\hline
\end{tabular}

Tablo 6'daki varyans analizi sonuçlarına göre, MiY puanlarında yaşantının çoğunun geçirildiği yerlere göre anlamlı farklılık olduğu görülmektedir. (F $\quad(3-383)=6,507, \quad \mathrm{p}<.01)$. Farklılığın hangi gruplar arasında olduğunu belirlemek için Tukey testi yapılmıştır. Testin sonuçlarına göre, yaşantısının çoğunu büyükşehirde geçiren adayların puanlarının $(\bar{X}$ $=40.42)$; il $(\bar{X}=33.74)$, ilçe $(\bar{X}=28.99)$ ve kasabaköy $(\bar{X}=28.81)^{\prime}$ de geçiren adaylara göre anlamlı farklılık gösterdiği görülmektedir.

Adayların MiY puanlarının yaşantının çoğunun geçirildiği bölgeye göre Kruskal-Wallis testi sonuçları Tablo 7'de yer almaktadır. 
Tablo 7. MIY Alanı Puanlarının Yaşantının Çoğunun Geçirildiği Bölgeye Göre Kruskal-Wallis Testi Sonuçları

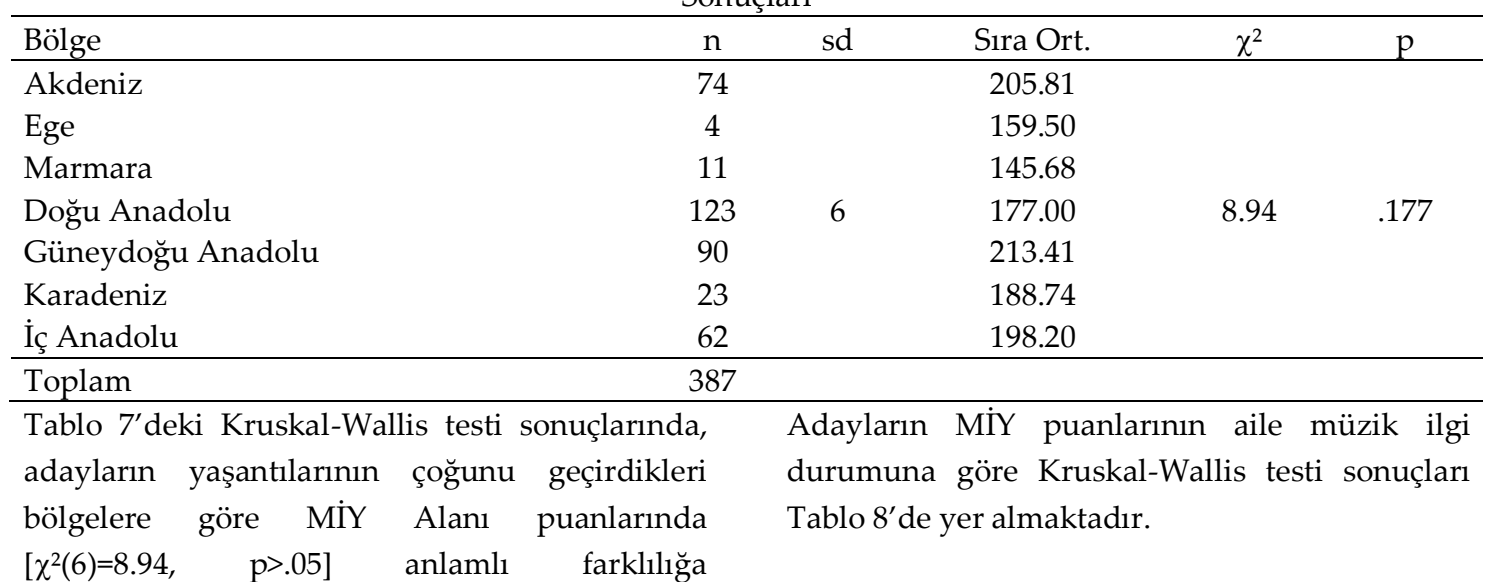
rastlanmamıştır.

Tablo 8. MiYY Alanı Puanlarının Aile Müzik İlgi Durumuna Göre Kruskal-Wallis Testi Sonuçları

\begin{tabular}{|c|c|c|c|c|c|}
\hline Aile Müzik İlgi Durumu & $\mathrm{n}$ & $\mathrm{sd}$ & Sira Ort. & $\chi^{2}$ & $\mathrm{p}$ \\
\hline Yok & 80 & \multirow{5}{*}{4} & 190.87 & \multirow{5}{*}{3.571} & \multirow{5}{*}{.467} \\
\hline Dinleyici & 111 & & 182.28 & & \\
\hline Amatör Düzeyde & 136 & & 196.69 & & \\
\hline Müzik Eğitimcisi & 52 & & 217.06 & & \\
\hline Besteci-İcracı & 8 & & 192.19 & & \\
\hline Toplam & 387 & & & & \\
\hline $\begin{array}{l}\text { Tablo } 8^{\prime} \text { deki Kruskal- } W \\
\text { göre, aile müzik ilgi durı } \\
\text { puanlarında }\left[\chi^{2}(4)=3.571,\right. \\
\text { rastlanmamıştır. }\end{array}$ & $\begin{array}{l}\text { i sonuçlarına } \\
\text { jre MİY Alanı } \\
\text { amlı farklılığa }\end{array}$ & \multicolumn{4}{|c|}{$\begin{array}{l}\text { Adayların MiY Alanı puanlarının aile aylık gelir } \\
\text { durumuna göre Kruskal-Wallis Testi sonuçlar } \\
\text { Tablo 9'da yer almaktadır. }\end{array}$} \\
\hline
\end{tabular}

Tablo 9. MIY Alanı Puanlarının Aile Aylık Gelir Durumuna Göre Kruskal-Wallis Testi Sonuçları

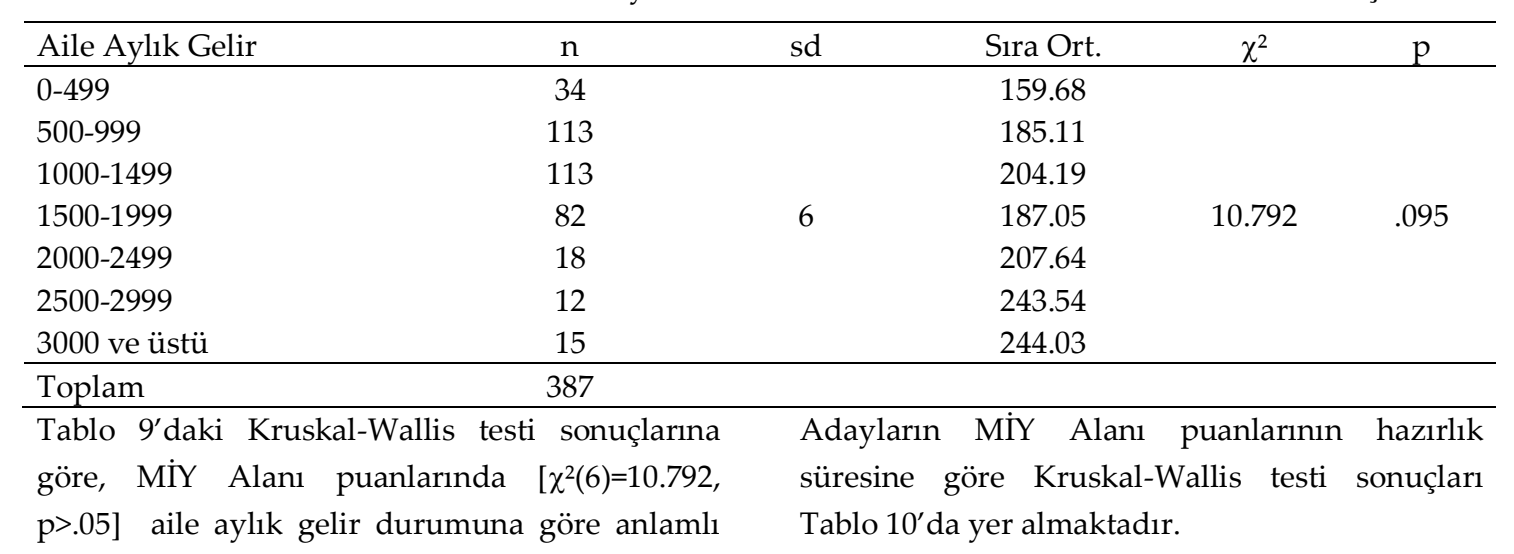
farklılığa rastlanmamıştır. 
Tablo 10. MIY Alanı Puanlarının Sınavlara Hazırlık Süresine Göre Kruskal-Wallis Testi Sonuçları

\begin{tabular}{lccccc}
\hline Hazırlık Süresi & $\mathrm{n}$ & sd & Sira Ort. & $\chi^{2}$ & $\mathrm{p}$ \\
\hline 6 aydan az & 56 & & 136.83 & & \\
6 ay-1 yıl & 82 & & 155.85 & & \\
1 yıl 1 gün-2yıl & 40 & & 203.09 & & \\
2 yıl 1 gün-3 yıl & 22 & 6 & 175.48 & 43.536 & .000 \\
3yll 1gün-4 y1l & 4 & & 247.75 & & \\
4 yıl 1gün-5 yıl & 153 & & 223.96 & \\
5 yıldan fazla & 30 & 246.50 & & \\
\hline Toplam & 387 & & & \\
\hline
\end{tabular}

Tablo $10^{\prime}$ daki Kruskal-Wallis testi sonuçlarına göre, MIY Alanı puanlarında $\left[\chi^{2}(6)=43.536\right.$, $\mathrm{p}<.01]$ adayların sınavlara hazırlık süresine göre anlamlı farklılık olduğu görülmektedir. Farklılıkların hangi gruplar arasında olduğunu saptamak için, grupların ikili kombinasyonları üzerinden Mann-Whitney U testi uygulanmıştır. 6 aydan az ve 6 ay-1 yll süre dilimlerinde hazırlananlara göre; 1 yıl 1 gün-2 yıl, 4 yıl 1 gün5 yıl ve 5 yıldan fazla hazırlananların daha başarılı oldukları ve farkların anlamlı olduğu bulunmuştur. Aynı zamanda 2 yıl 1 gün-3 yıl

Tablo 11. MIY Alanı Puanlarının Sınavlara Hazırlanma Biçimine Göre Kruskal-Wallis Testi Sonuçları

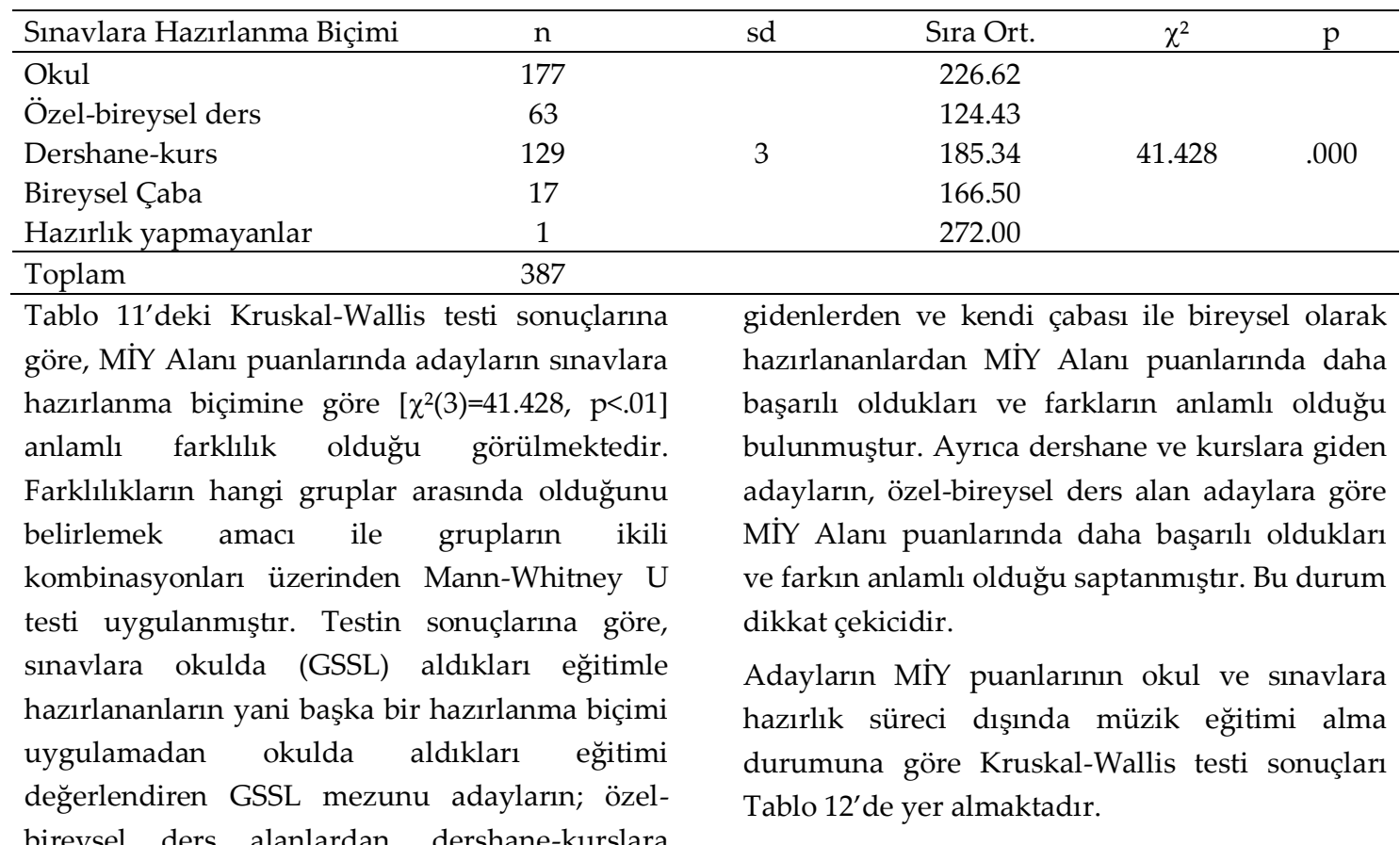
2 yıl 1 gün-3 yıl arasinda hazırlananlar ile 5 farklılıklar olduğu sonucu bulunmuş, 4 yıl 1 gün5 yil ve 5 yıldan fazla hazırlananların MiY Alanında daha yüksek puanlar aldıkları tespit edilmiştir.

Adayların MiY puanlarının sınava yönelik eğitim aldığı yer-yönteme, hazırlanma biçimine göre Kruskal-Wallis testi sonuçları Tablo 11'de yer almaktadır. arasında hazırlananlar ile 4 yıl 1 gün-5 yıl ve yine yıldan fazla hazırlananların arasında anlamlı

bireysel ders alanlardan, dershane-kurslara 
Tablo 12. MIY Alanı Puanlarının Okul ve Sınavlara Hazırlık Süreci Dışında Müzik Eğitimi Alma Durumuna Göre Kruskal-Wallis Testi Sonuçları

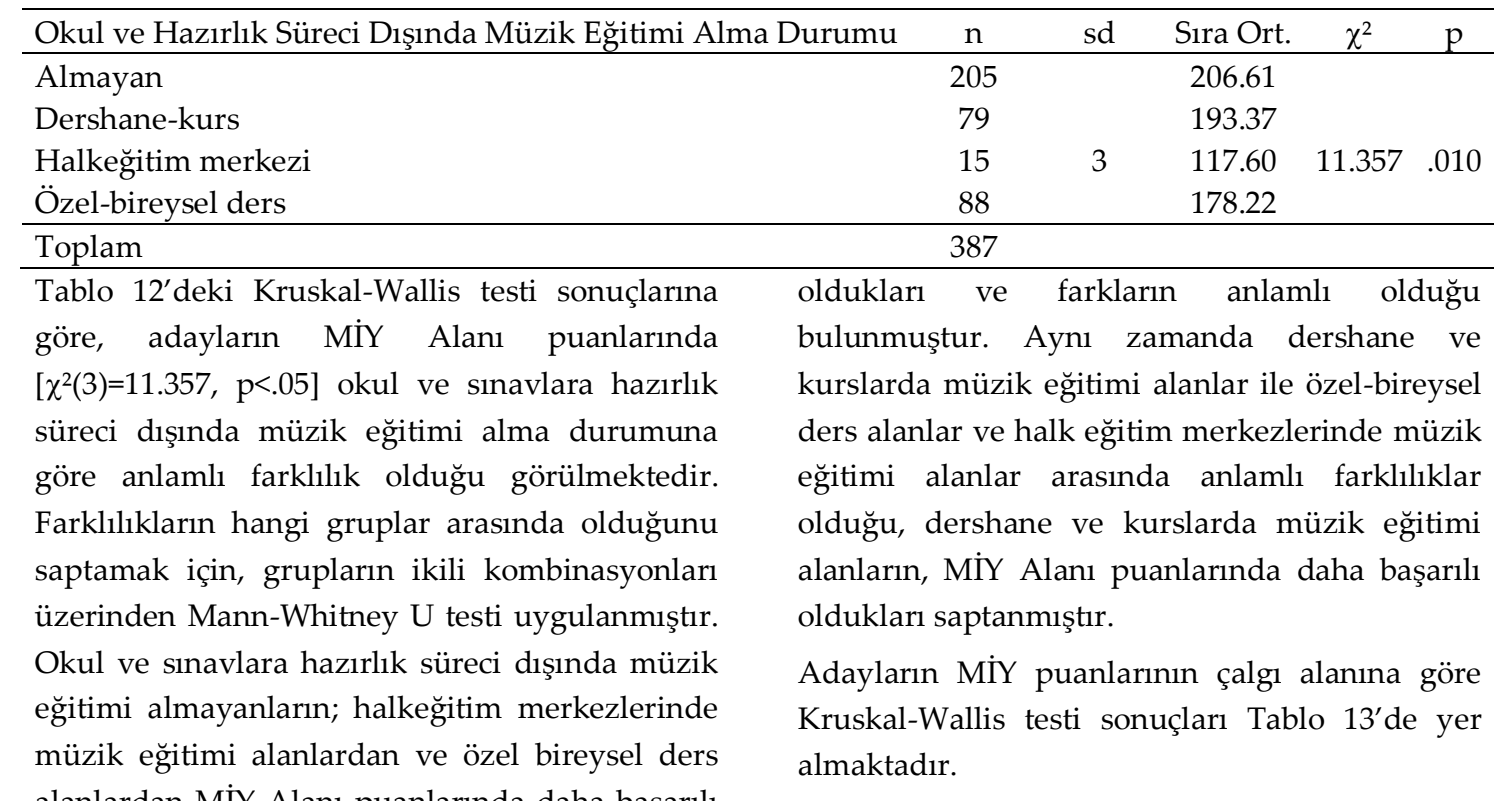
alanlardan MiY Alanı puanlarında daha başarılı

Tablo 13. MIY Alanı Puanlarının Çalgı Alanına Göre Kruskal-Wallis Testi Sonuçları

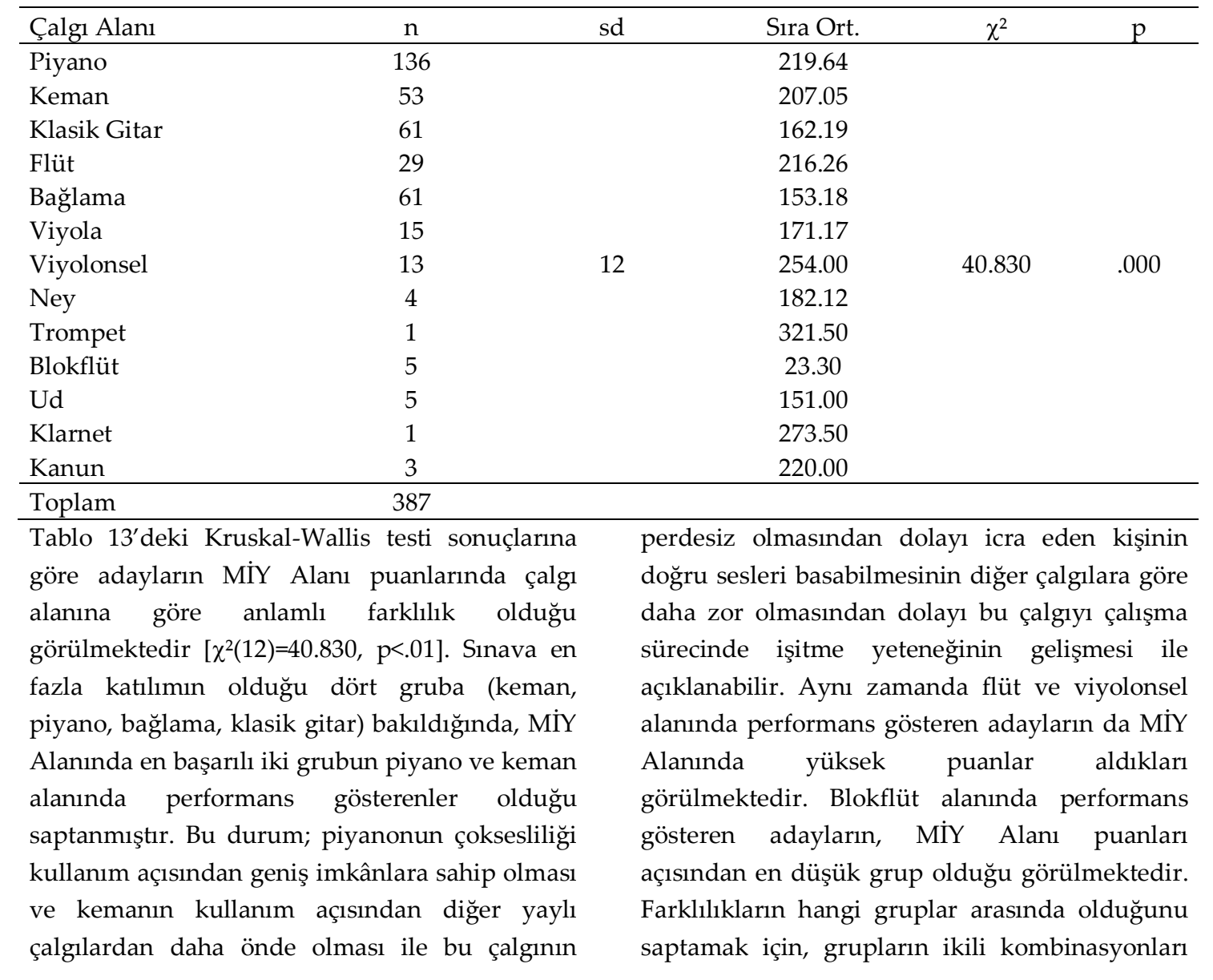


üzerinden Mann-Whitney U testi uygulanmıştır. Piyano ve keman alanında performans gösteren adayların; klasik gitar, bağlama ve viyolonsel alanında performans gösteren adaylardan MIY Alanı puanlarının daha yüksek olduğu ve farkların anlamlı olduğu bulunmuştur.

MiY Alanı puanları incelendiğinde; çalgı alanı klasik gitar olanların; piyano, keman, flüt ve viyolonsel olan adaylardan daha başarısız oldukları, blokflüt olanlardan ise daha başarılı oldukları ve farkların anlamlı olduğu saptanmıştır. Çalgı alanı flüt olan adayların, MIYY Alanı puanlarının; bağlama, blokflüt ve klasik gitar olan adaylardan daha yüksek olduğu ve farkların anlamlı olduğu bulunmuştur. Çalgı alanı bağlama olan adayların; piyano, keman, flüt ve viyolonsel olan adaylardan MiY Alanı puanlarının daha düşük; blokflüt olanlardan ise daha yüksek olduğu ve farkların anlamlı olduğu tespit edilmiştir. Çalgı alanı viyola olanların; blokflüt olan adaylara göre daha başarılı oldukları, viyolonsel olan adaylara göre daha başarısız oldukları ve farkların anlamlı olduğu saptanmıştır. Çalgı alanı viyolonsel olan adayların, MIY Alanı puanları incelendiğinde; klasik gitar, viyola, bağlama ve blokflüt olan adaylardan daha başarılı oldukları ve farkların anlamlı olduğu tespit edilmiştir. Çalgı alanı ney, ud ve kanun olanlar ile blokflüt olanların arasında anlamlı farklılıklar olduğu ve blokflüt olanların puanlarının en geride kaldığı görülmektedir.

3.2.2. Çeşitli Değişsenler ile Müziksel Çalma Alanı Puanları Arasındaki İlişkilere Yönelik Bulgular

İkinci Aşama Sınavına girmeye hak kazanan adayların, Müziksel Çalma Alanı puanlarının cinsiyete göre Mann-Whitney U Testi sonuçları Tablo 14' de yer almaktadır.

Tablo 14. Müziksel Çalma Alanı Puanlarının Cinsiyete Göre Mann-Whitney U Testi Sonuçları

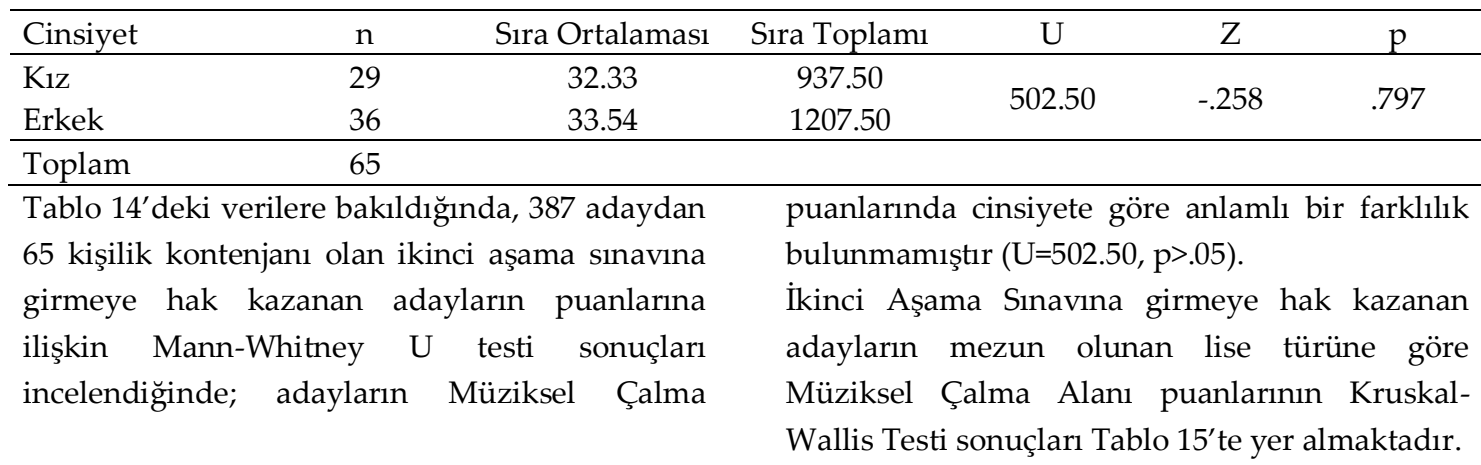

Tablo 15. Müziksel Çalma Alanı Puanlarının Mezun Olunan Lise Türüne Göre Kruskal-Wallis Testi Sonuçları

\begin{tabular}{|c|c|c|}
\hline Lise Türü & sd & Sira Ort. \\
\hline GSSL & & 37.15 \\
\hline Genel Lise & 2 & 9.625 \\
\hline Diğer & & 12.50 \\
\hline Toplam & & \\
\hline $\begin{array}{l}\text { Tablo } 15^{\prime} \text { deki Kruskal-Wallis testi sonuçlarına } \\
\text { göre, ikinci aşama sinavına giren adayların } \\
\text { Müziksel Çalma Alanı puanlarında }\left[\chi^{2}(2)=9.625 \text {, }\right. \\
\text { p<.01] mezun olunan lise türüne göre anlamll } \\
\text { farklılık olduğu görülmektedir. Farklılıkların } \\
\text { hangi gruplar arasında olduğunu saptamak için, } \\
\text { grupların ikili kombinasyonları üzerinden } \\
\text { Mann-Whitney U testi uygulanmıştır. Bu } \\
\text { testlerin sonuçlarına göre GSSL mezunu }\end{array}$ & & $\begin{array}{l}\text { adayların puanlarının; Genel Lise ve diğer lise } \\
\text { türlerinden mezun olan adayların puanlarına } \\
\text { göre anlamlı farklılık gösterdiği ve GSSL } \\
\text { mezunu adayların Müziksel Çalma Alanı } \\
\text { puanlarının daha yüksek olduğu saptanmıştır. } \\
\text { Bu durum; GSSL mezunlarının ortaöğretim } \\
\text { kademesinde bireysel çalgı dersi almalarından } \\
\text { dolayı, çalgı alanında diğer adaylardan daha } \\
\text { avantajlı bir konumda olmaları ile açılanabilir. }\end{array}$ \\
\hline
\end{tabular}


İkinci Aşama Sınavına girmeye hak kazanan adayların yaşantının çoğunun geçirildiği yere göre Müziksel Çalma Alanı puanlarının KruskalWallis testi sonuçları Tablo 16 'da yer almaktadır.

Tablo 16. Müziksel Çalma Alanı Puanlarının Yaşantının Çoğunun Geçirildiği Yere Göre Kruskal-Wallis Testi Sonuçları

\begin{tabular}{|c|c|c|c|c|c|}
\hline Yer & $\mathrm{n}$ & $\mathrm{sd}$ & Sira Ort. & $\chi^{2}$ & $p$ \\
\hline Büyükşehir & 25 & \multirow{4}{*}{3} & 37.56 & \multirow{4}{*}{4.607} & \multirow{4}{*}{.203} \\
\hline İ & 34 & & 23.94 & & \\
\hline İlçe & 4 & & 30.75 & & \\
\hline Kasaba-Köy & 2 & & 49.50 & & \\
\hline Toplam & 65 & & & & \\
\hline $\begin{array}{l}\text { Tablo } 16 \text { 'daki } \\
\text { bakıldığında, } \\
{\left[\chi^{2}(3)=4.607,\right.} \\
\text { geçirildiği ye } \\
\text { görïilmektedi }\end{array}$ & $\begin{array}{l}\text { ki Kruskal-Wallis testi sonuçlarına } \\
\text { Müziksel Çalma Alanı puanlarında } \\
\text { p >.05] yaşantının çoğunun } \\
\text { ere göre anlamlı farklılık olmadığ } \\
\text { ir }\end{array}$ & & $\begin{array}{l}\text { İkinci Aşama Sınav } \\
\text { adayların yaşantının } \\
\text { göre Müziksel Çalmə } \\
\text { Wallis testi sonuçları }\end{array}$ & $\begin{array}{l}\text { irmeye } \\
\text { un geçi } \\
\text { puanla } \\
17^{\prime} \text { de y }\end{array}$ & $\begin{array}{l}\text { kazanan } \\
\text { bölgeye } \\
\text { Kruskal- } \\
\text { aktadır. }\end{array}$ \\
\hline
\end{tabular}
görülmektedir.

Tablo 17. Müziksel Çalma Alanı Puanlarının Yaşantının Çoğunun Geçirildiği Bölgeye Göre KruskalWallis Testi Sonuçları

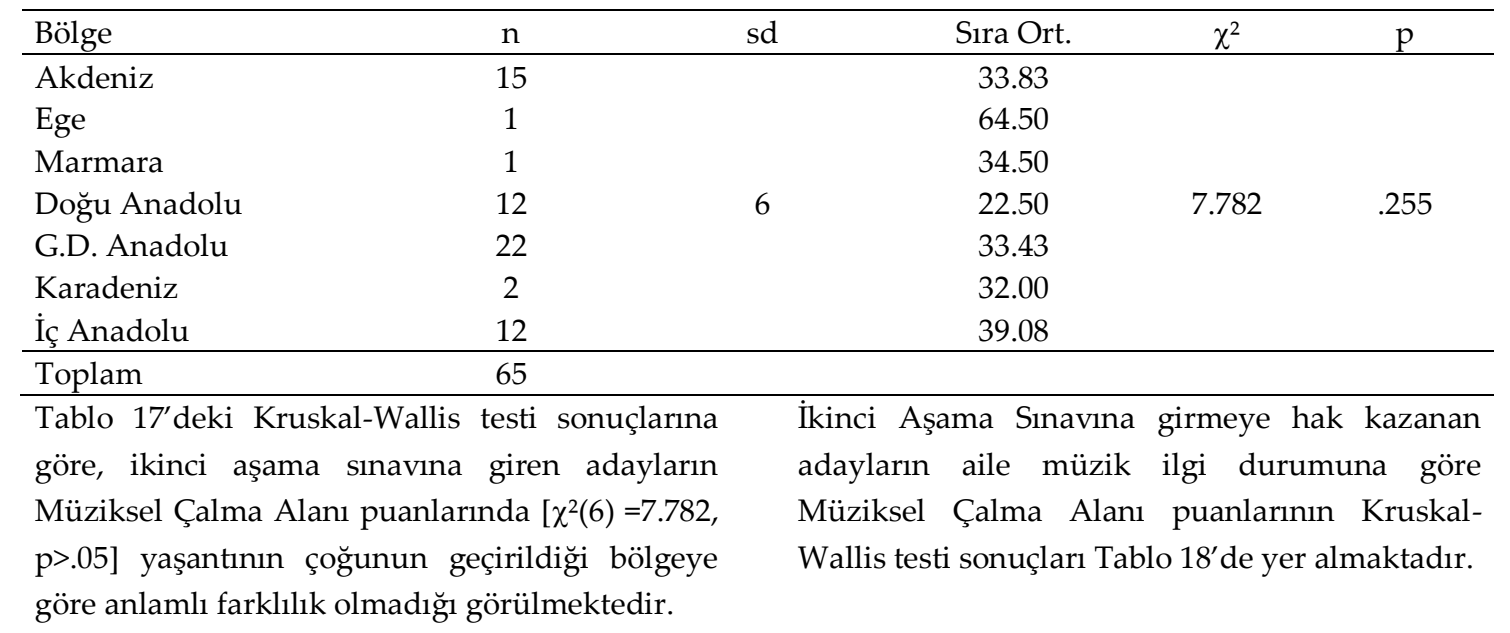

Tablo 18. Müziksel Çalma Alanı Puanlarının Aile Müzik İlgi Durumuna Göre Kruskal-Wallis Testi Sonuçları

\begin{tabular}{|c|c|c|c|c|c|}
\hline Aile Müzik İlgi Durumu & $\mathrm{n}$ & $\mathrm{sd}$ & Sira Ort. & $\chi^{2}$ & $\mathrm{p}$ \\
\hline Yok & 13 & \multirow{5}{*}{4} & 31.35 & \multirow{5}{*}{1.536} & \multirow{5}{*}{.820} \\
\hline Dinleyici & 17 & & 34.38 & & \\
\hline Amatör Düzeyde & 24 & & 35.40 & & \\
\hline Müzik Eğitimcisi & 9 & & 26.94 & & \\
\hline Besteci-İcrac1 & 2 & & 30.50 & & \\
\hline Toplam & 65 & & & & \\
\hline $\begin{array}{l}\text { Tablo } 18^{\prime} \text { deki Kruskal- } И \\
\text { göre, ikinci aşama sın } \\
\text { Müziksel Çalma Alanı } \\
\text { p>.05] aile müzik ilgi d }\end{array}$ & $\begin{array}{l}\text { sonuçlarına } \\
n \quad \text { adayların } \\
{\left[\chi^{2}(4)=1.536,\right.} \\
\text { göre anlamlı }\end{array}$ & & $\begin{array}{l}\text { na Sınavın } \\
\text { aile aylık } \\
\text { Çalma Ala } \\
\text { sonuçları Tc }\end{array}$ & $\begin{array}{l}\text { meye } \\
\text { r dur } \\
\text { uanları } \\
9^{\prime} \text { da ye }\end{array}$ & $\begin{array}{l}\text { kazanan } \\
\text { la göre } \\
\text { Kruskal- } \\
\text { aktadır. }\end{array}$ \\
\hline
\end{tabular}

farklılık olmadığı görülmektedir. 
Tablo 19. Müziksel Çalma Alanı Puanlarının Aile Aylık Gelir Durumuna Göre Kruskal Wallis Testi Sonuçları

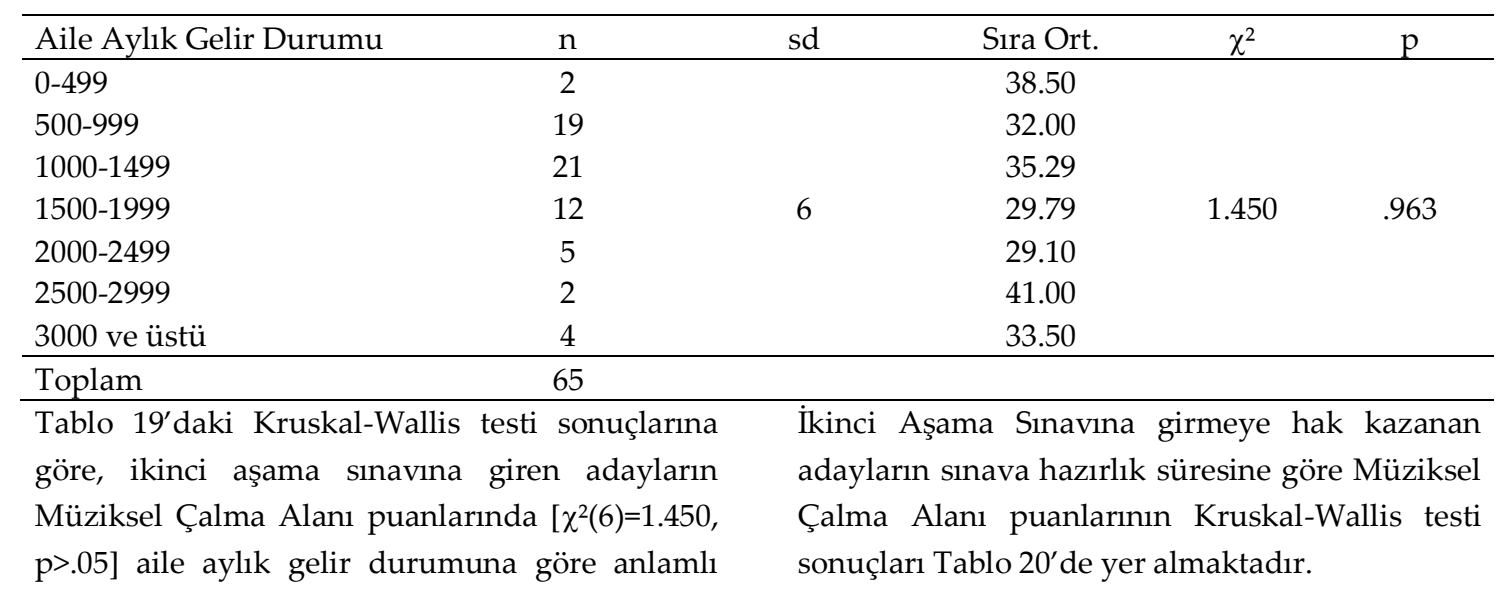
farklılık olmadığı görülmektedir.

Tablo 20. Müziksel Çalma Alanı Puanlarının Sınavlara Hazırlık Süresine Göre Kruskal-Wallis Testi Sonuçları

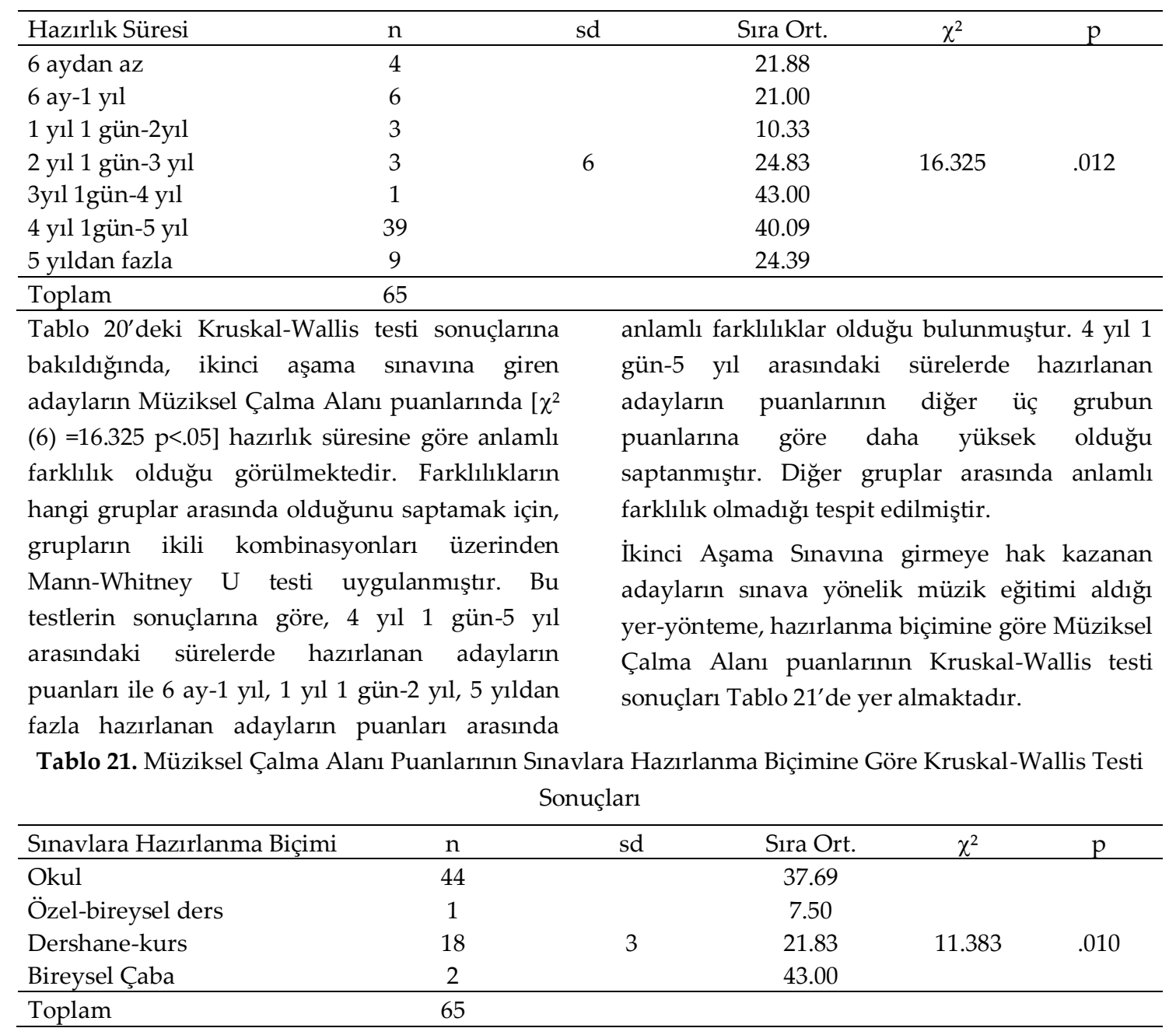


Tablo 21'deki Kruskal-Wallis testi sonuçlarına bakıldığında, ikinci aşama sinavına giren adayların Müziksel Çalma Alanı puanlarında $\left[\chi^{2}(3)=11.383, \quad p<.05\right] \quad$ sinavlara hazırlanma biçimine göre anlamlı farklılık olduğu görülmektedir. Farklılıkların hangi gruplar arasında olduğunu saptamak için, grupların ikili kombinasyonları üzerinden Mann-Whitney U testi uygulanmıştır. Bu testlerin sonuçlarına göre, GSSL'lerde aldıkları eğitimle sınavlara hazırlanan adayların Müziksel Çalma Alanı puanları ile dershane ve kurslarda hazırlanan adayların Müziksel Çalma Alanı puanları arasında anlamlı farklılık olduğu bulunmuştur. Okulda aldıkları eğitimle hazırlananların puanlarının daha yüksek olduğu tespit edilmiştir. Bu durumun GSSL'lerde bireysel çalg1 dersinin olması ve bu okullardan mezun adayların çalgı eğitimi almış olmalarından kaynaklandığı düşünülebilir.

İkinci Aşama Sınavına girmeye hak kazanan adayların okul ve sınavlara hazırlık süreci dışında müzik eğitimi alma durumuna göre Müziksel Çalma Alanı puanlarının KruskalWallis testi sonuçları Tablo 22 'de yer almaktadir.

Tablo 22. Müziksel Çalma Alanı Puanlarının Okul ve Sınavlara Hazırlık Süreci Dışında Müzik Eğitimi Alma Durumuna Göre Kruskal-Wallis Testi Sonuçları

\begin{tabular}{|c|c|c|c|c|c|c|}
\hline \multicolumn{2}{|c|}{ Okul ve Hazırlık Süreci Dışında Müzik Eğitimi Alma Durumu } & \multirow{2}{*}{$\frac{\mathrm{n}}{41}$} & sd & Sira Ort. & $\chi^{2}$ & $\mathrm{p}$ \\
\hline Almadim & & & & 36.98 & & \\
\hline Dershane-kurs & & 15 & & 27.43 & & \\
\hline Halkeğitim merkezi & & 2 & 3 & 25.50 & 5.097 & .165 \\
\hline Özel-bireysel ders & & 7 & & 23.79 & & \\
\hline Toplam & & 65 & & & & \\
\hline $\begin{array}{l}\text { Tablo 22'deki Kruskal-Wallis testi sonuçlarına } \\
\text { göre, adayların Müziksel Çalma Alanı } \\
\text { puanlarında }\left[\chi^{2} \quad(3)=5.097, \text { p }>05\right] \text { okul ve } \\
\text { sınavlara hazırlık süreci dışında müzik eğitimi }\end{array}$ & $\begin{array}{l}\text { alma di } \\
\text { görülme } \\
\text { Adaylaı } \\
\text { Alanı p } \\
\text { Tablo 23 }\end{array}$ & $\begin{array}{l}\text { Imun } \\
\text { edir. } \\
\text { çalg } \\
\text { nlarır } \\
\text { yer }\end{array}$ & & $\begin{array}{l}\text { mlı farklılı } \\
\text { öre Müzil } \\
\text { Wallis tes }\end{array}$ & k olme & $\begin{array}{l}\text { adığı } \\
\text { alma } \\
\text { çları }\end{array}$ \\
\hline
\end{tabular}

Tablo 23. Müziksel Çalma Alanı Puanlarının Çalgı Alanına Göre Kruskal-Wallis Testi Sonuçları

\begin{tabular}{lccccc}
\hline Çalgı Alanı & $\mathrm{n}$ & sd & Sira Ort. & $\chi^{2}$ & $\mathrm{p}$ \\
\hline Piyano & 29 & & 30.93 & & \\
Keman & 15 & & 34.80 & & \\
Klasik Gitar & 3 & & 15.17 & & \\
Flüt & 7 & 7 & 34.79 & & \\
Bağlama & 5 & 35.20 & 6.296 & .506 \\
Viyola & 1 & 38.50 & & \\
Viyolonsel & 4 & & 40.12 & & \\
Kanun & 1 & 62.00 & & \\
\hline Toplam & 65 & & & &
\end{tabular}

Tablo $23^{\prime}$ deki Kruskal-Wallis testi sonuçlarına bakıldığında, ikinci aşama sınavına giren adayların Müziksel Çalma puanlarında $\left[\chi^{2}(7)=6.296, p>.05\right]$ çalg1 alanına göre anlamlı farklılık olmadığı görülmektedir. İlk aşamaya giren adayların çalgı alanına göre Mï Alanı puanlarında anlamlı farklılık $\left[\chi^{2}(12)=40.830\right.$, $\mathrm{p}<.01]$ olmasına rağmen, Müziksel Çalma Alanı puanlarında anlamlı farklılık bulunamaması dikkat çekicidir. İkinci aşamaya giren adayların çalgı alanlarında belirli bir düzeyde yeterliliğe sahip olmalarından dolayı birbirlerinden çok yüksek veya çok düşük puanlar almamaları sebebiyle anlamlı farklılığın oluşmadı̆̆ 1 düşünülebilir.

3.2.3. Çeşitli Değişkenler ile Müziksel Söyleme Alanı Puanları Arasındaki İlişkilere Yönelik Bulgular 
İkinci Aşama Sınavına girmeye hak kazanan puanlarının Mann-Whitney U Testi sonuçları adayların cinsiyete göre Müziksel Söyleme Alanı Tablo 24' de yer almaktadır.

Tablo 24. Müziksel Söyleme Alanı Puanlarının Cinsiyete Göre Mann-Whitney U Testi Sonuçları

\begin{tabular}{lcccccc}
\hline Cinsiyet & $\mathrm{N}$ & Sira Ortalaması & Sira Toplamı & U & Z & $\mathrm{p}$ \\
\hline Kiz & 29 & 34.57 & 1002.50 & \multirow{2}{*}{476.500} & -.601 & .548 \\
Erkek & 36 & 31.74 & 1142.50 & & & \\
\hline Toplam & 65 & & & & &
\end{tabular}

Tablo 24'deki verilere bakıldığında 387 adaydan 65 kişilik kontenjanı olan ikinci aşama sınavı girmeye hak kazanan adayların puanlarına ilişkin Mann-Whitney U testi sonuçları incelendiğinde; adayların Müziksel Söyleme İkinci Aşama Sınavına girmeye hak kazanan adayların mezun olunan lise türüne göre Müziksel Söyleme Alanı puanlarının KruskalWallis Testi sonuçları Tablo 25'de yer Alanı puanlarında cinsiyete göre anlamlı bir farklılık bulunmamıştır ( $U=476.50, \mathrm{p}>.05)$.

Tablo 25. Müziksel Söyleme Alanı Puanlarının Mezun Olunan Lise Türüne Göre Kruskal-Wallis Testi Sonuçları

\begin{tabular}{lccccc}
\hline Lise Türü & $\mathrm{n}$ & $\mathrm{sd}$ & Sira Ort. & $\chi^{2}$ & $\mathrm{p}$ \\
\hline GSSL & 48 & & 35.09 & & \\
Genel Lise & 14 & 2 & 26.71 & 2.282 & .320 \\
Diğer & 3 & & 28.83 & & \\
\hline Toplam & 65 & & & & \\
\hline
\end{tabular}

Tablo 25'deki Kruskal-Wallis testi sonuçlarına göre, ikinci aşama sınavına giren adayların Müziksel Söyleme Alanı puanlarında $\left[\chi^{2}\right.$ (2) $=2.282, p>$.05] mezun olunan lise türüne göre anlamlı farklılık olmadığı görülmektedir. Lise türüne göre MIY puanlarında ( $F(2,384)=23,17$, $\mathrm{p}<.01)$ ve Müziksel Çalma Alanı puanlarında $\left[\chi^{2}(2)=9.625, \quad p<.01\right]$ anlaml $\quad$ bir farkl1lı

oluşurken, Müziksel Söyleme Alanı puanlarında farklılı̆̆ın oluşmaması dikkat çekicidir.

İkinci Aşama Sınavına girmeye hak kazanan adayların, yaşantının çoğunun geçirildiği yere göre Müziksel Söyleme Alanı puanlarının Kruskal-Wallis Testi sonuçları Tablo 24'te yer almaktadır.

Tablo 26. Müziksel Söyleme Alanı Puanlarının Yaşantının Çoğunun Geçirildiği Yere Göre KruskalWallis Testi Sonuçları

\begin{tabular}{lccccc}
\hline Yer & $\mathrm{n}$ & sd & Sıra Ort. & $\chi^{2}$ & $\mathrm{p}$ \\
\hline Büyükşehir & 25 & & 30.34 & & \\
İl & 34 & 3 & 33.24 & 2.568 & .463 \\
İlçe & 4 & & 39.00 & & \\
Kasaba-Köy & 2 & & 50.25 & & \\
\hline Toplam & 65 & & & \\
\hline
\end{tabular}

Tablo $26^{\prime}$ daki Kruskal-Wallis testi sonuçlarına göre, ikinci aşama sınavına giren adayların Müziksel Söyleme Alanı puanlarında $\left[\chi^{2}(3)=2.568, \quad p>.05\right] \quad$ yaşantının çoğunun geçirildiği yere göre anlamlı farklılık olmadığı görülmektedir.
İkinci Aşama Sınavına girmeye hak kazanan adayların, yaşantının çoğunun geçirildiği bölgeye göre Müziksel Söyleme Alanı puanlarının Kruskal-Wallis Testi sonuçları Tablo 27 'de yer almaktadır. 
Tablo 27. Müziksel Söyleme Alanı Puanlarının Yaşantının Çoğunun Geçirildiği Bölgeye Göre KruskalWallis Testi Sonuçları

\begin{tabular}{|c|c|c|c|c|c|}
\hline Bölge & $\mathrm{n}$ & sd & Sira Ort. & $\chi^{2}$ & $\mathrm{p}$ \\
\hline Akdeniz & 15 & \multirow{7}{*}{6} & 34.33 & \multirow{7}{*}{6.352} & \multirow{7}{*}{.385} \\
\hline Ege & 1 & & 52.00 & & \\
\hline Marmara & 1 & & 8.00 & & \\
\hline Doğu Anadolu & 12 & & 32.29 & & \\
\hline Güneydoğu Anadolu & 22 & & 28.16 & & \\
\hline Karadeniz & 2 & & 42.00 & & \\
\hline İç Anadolu & 12 & & 39.92 & & \\
\hline Toplam & 65 & & & & \\
\hline $\begin{array}{l}\text { Tablo } 27^{\prime} \text { deki Kruské } \\
\text { göre, ikinci aşama } \\
\text { Müziksel Söyleme } \\
=6.352 \text {, p }>.05] \text { yaşan } \\
\text { bölgeye göre anla }\end{array}$ & $\begin{array}{l}\text { testi sonuçlarına } \\
\text { giren adayların } \\
\text { puanlarında }\left[\odot^{2}(6)\right. \\
\text { ğunun geçirildiği } \\
\text { arklılık olmadığ }\end{array}$ & \multicolumn{4}{|c|}{$\begin{array}{l}\text { İkinci Aşama Sınavına girmeye hak kazanan } \\
\text { adayların, aile müzik ilgi durumuna göre } \\
\text { Müziksel Söyleme Alanı puanlarının Kruskal- } \\
\text { Wallis Testi sonuçları Tablo } 28^{\prime} \text { de yer } \\
\text { almaktadır. }\end{array}$} \\
\hline
\end{tabular}
görülmektedir.

Tablo 28. Müziksel Söyleme Alanı Puanlarının Aile Müzik İlgi Durumuna Göre Kruskal-Wallis Testi Sonuçları

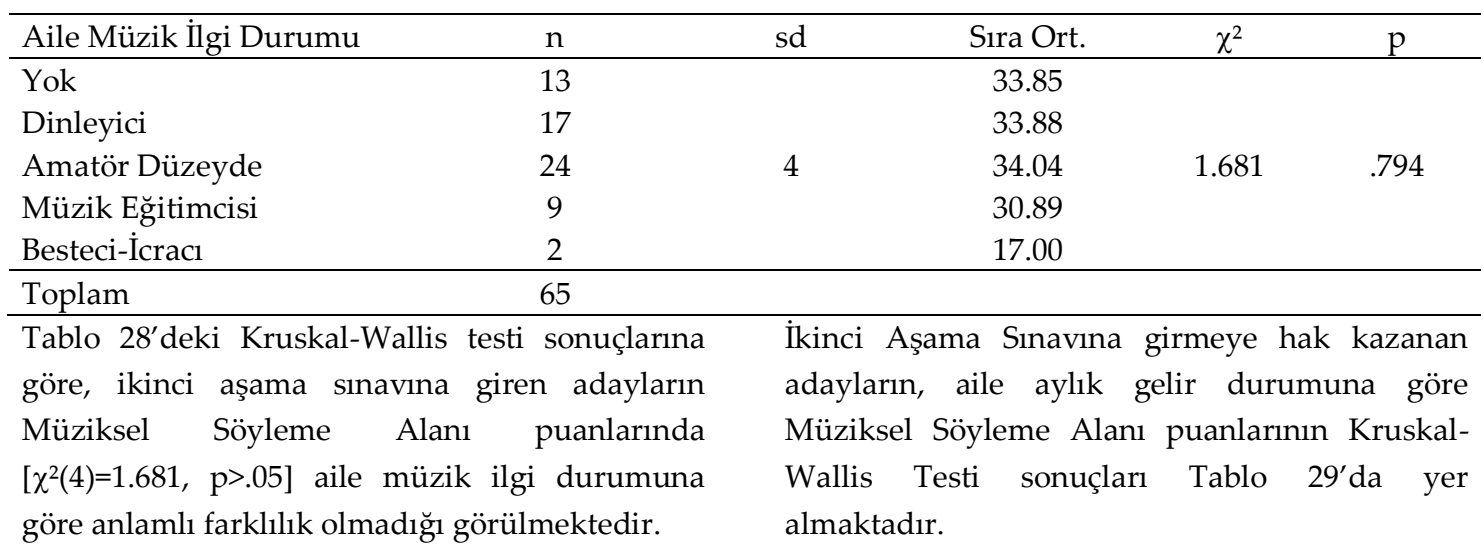

Tablo 29. Müziksel Söyleme Alanı Puanlarının Aile Aylık Gelir Durumuna Göre Kruskal-Wallis Testi Sonuçları

\begin{tabular}{|c|c|c|c|c|c|}
\hline Aile Aylık Gelir Durumu & $\mathrm{n}$ & $\mathrm{sd}$ & Sira Ort. & $\chi^{2}$ & $\mathrm{p}$ \\
\hline $0-499$ & 2 & \multirow{7}{*}{6} & 41.50 & \multirow{7}{*}{2.501} & \multirow{7}{*}{.868} \\
\hline 500-999 & 19 & & 33.39 & & \\
\hline $1000-1499$ & 21 & & 35.29 & & \\
\hline 1500-1999 & 12 & & 31.38 & & \\
\hline $2000-2499$ & 5 & & 24.70 & & \\
\hline 2500-2999 & 2 & & 40.00 & & \\
\hline 3000 ve üstü & 4 & & 26.62 & & \\
\hline Toplam & 65 & & & & \\
\hline $\begin{array}{l}\text { Tablo } 29^{\prime} \text { daki Kruskal-W } \\
\text { göre, ikinci aşama sina } \\
\text { Müziksel Söyleme Alan } \\
=2.501, \text { p }>05 \text { ] aile aylık } \\
\text { anlamlı farklılık olmadığı }\end{array}$ & $\begin{array}{l}\text { sonuçlarına } \\
\text { en adayların } \\
\text { arında }\left[\chi^{2}(6)\right. \\
\text { umuna göre } \\
\text { tedir. }\end{array}$ & \multicolumn{4}{|c|}{$\begin{array}{l}\text { İkinci Aşama Sınavına girmeye hak kazanan } \\
\text { adayların sınavlara hazırlı süresine göre } \\
\text { Müziksel Söyleme Alanı puanlarının Kruskal } \\
\text { Wallis Testi sonuçları Tablo } 30^{\prime} \text { da yer } \\
\text { almaktadır. }\end{array}$} \\
\hline
\end{tabular}


Tablo 30. Müziksel Söyleme Alanı Puanlarının Hazırlık Süresine Göre Kruskal- Wallis Testi Sonuçları

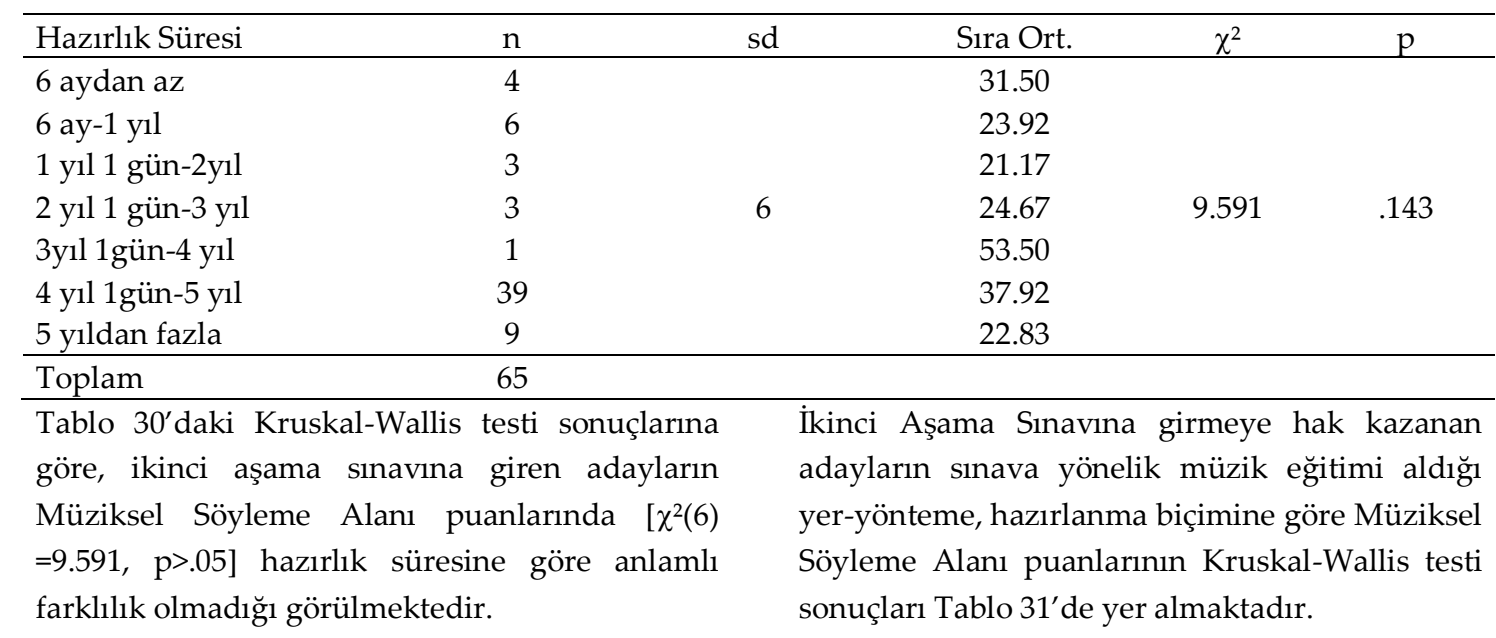

Tablo 31. Müziksel Söyleme Alanı Puanlarının Hazırlanma Biçimine Göre Kruskal-Wallis Testi Sonuçları

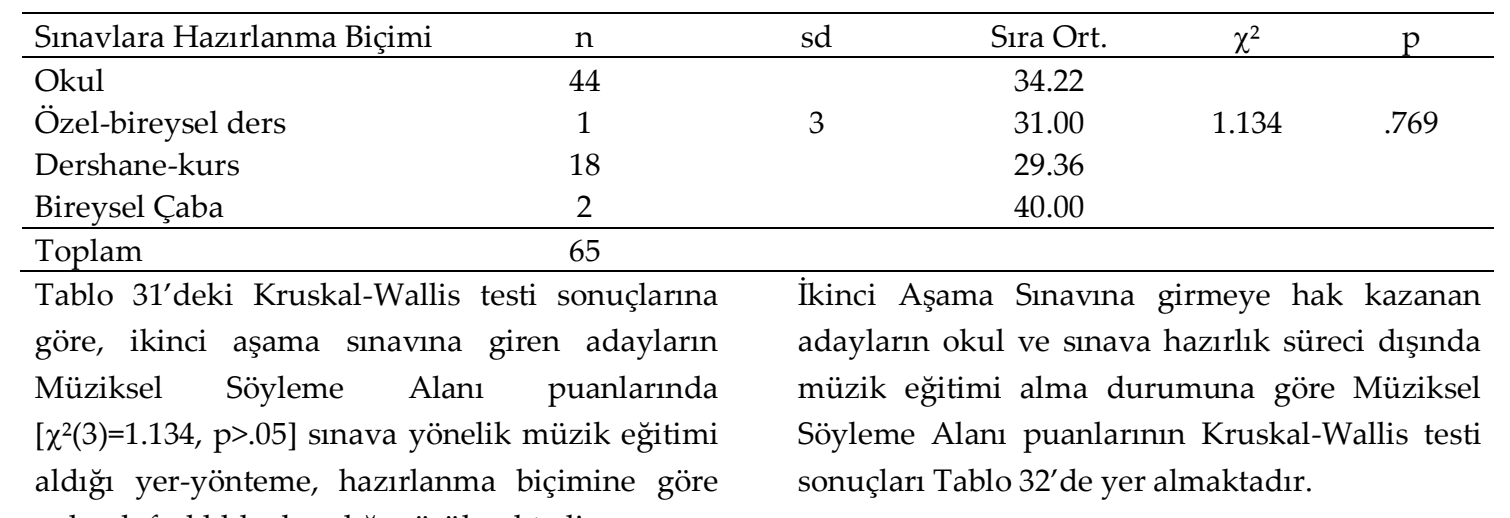
anlamlı farklılık olmadı ̆̆ı görülmektedir.

Tablo 32. Müziksel Söyleme Alanı Puanlarının Okul ve Sınavlara Hazırlık Süreci Dışında Müzik Eğitimi Alma Durumuna Göre Kruskal-Wallis Testi Sonuçları

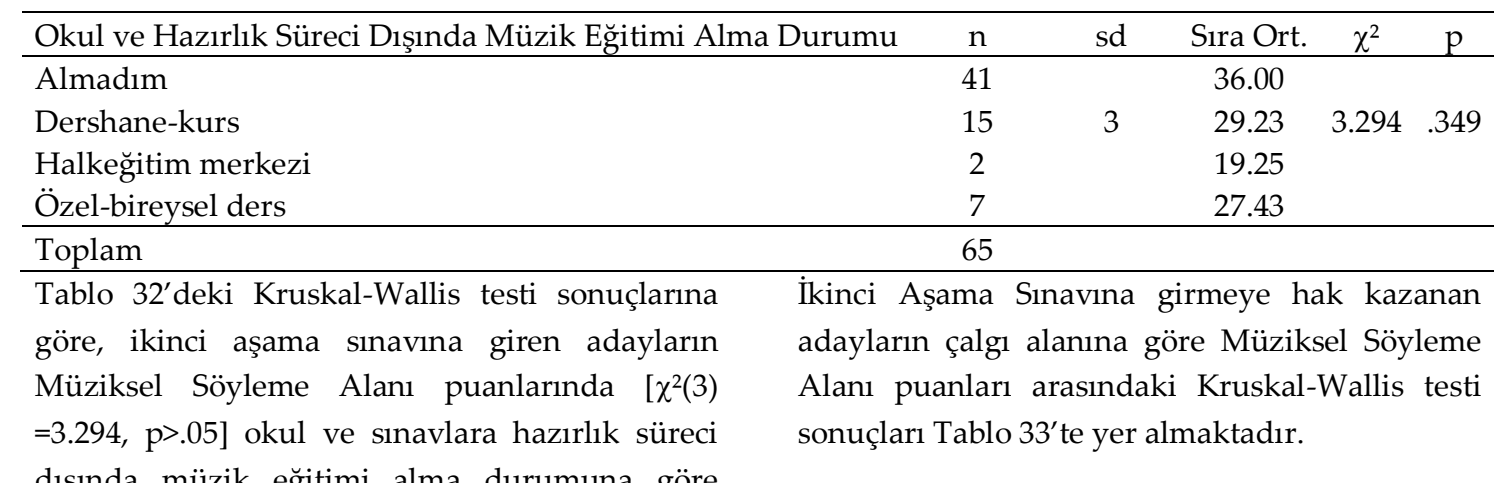
dışında müzik eğitimi alma durumuna göre anlamlı farklılık olmadığı görülmektedir. 
Tablo 33. Müziksel Söyleme Alanı Puanlarının Çalgı Alanına Göre Kruskal-Wallis Testi Sonuçları

\begin{tabular}{lccccc}
\hline Çalgı Alanı & $\mathrm{n}$ & sd & Sıra Ort. & $\chi^{2}$ & $\mathrm{p}$ \\
\hline Piyano & 29 & & 32.12 & & \\
Keman & 15 & & 35.57 & & \\
Klasik Gitar & 3 & & 12.83 & & \\
Flüt & 7 & & 29.93 & & \\
Bağlama & 5 & 7 & 33.30 & 9.727 & .205 \\
Viyola & 1 & & 13.00 & & \\
Viyolonsel & 4 & & 47.88 & & \\
Kanun & 1 & 61.00 & & \\
\hline
\end{tabular}

Toplam 65

Tablo 33'deki Kruskal-Wallis testi sonuçlarına Literatürde özel yetenek sınavlarına başvuran; bakıldığında, ikinci aşama sınavına giren adayların Müziksel Söyleme Alanı puanlarında $\left[\chi^{2}(7)=9.727, p>.05\right]$ çalg1 alanına göre anlamlı farklılık olmadığı görülmektedir.

\section{TARTIŞMA VE SONUÇ}

Adayların sosyo-demografik özelliklerinin dağılımına ilişkin sonuçlara bakıldığında;

- Cinsiyete göre erkek adayların sayısının, kız adayların sayısından daha fazla olduğu; yaşa göre yığılmanın, 17-20 yaş aralığında olduğu; mezun olunan lise türüne göre Güzel Sanatlar ve Spor Liseleri (GSSL) ve genel lise mezunu adayların çoğunlukta oldukları; yaşantının geçirildiği yere göre il ve büyükşehirlerde yaşayanların çoğunlukta oldukları; yaşantının geçirildiği bölgeye göre Doğu Anadolu Bölgesinde geçirenlerin sayısının daha fazla olduğu; anne-baba eğitim durumlarına göre, anneleri ilköğretim ve lise mezunu olan aday sayısının daha fazla olduğu; baba eğitim durumu açısından, babaları lise ve ilköğretim mezunu olan aday sayısının daha fazla olduğu; aile aylık gelir durumuna göre yığılmanın 500-1499 TL aralığında olduğu tespit edilmiştir.

Sağer, Zahal ve Gürpınar (2014) tarafından yapılan çalışmada da adayların sosyodemografik özelliklerinin dağılımına ilişkin benzer sonuçlara ulaşılmıştır. Bu durumun, araştırma kapsamında ele alınan üniversitenin aynı olmasından dolayı sınava başvuran adayların özellikle bölge ve kültür açısından benzer sosyo-demografik özelliklere sahip olmalarından kaynaklandığı düşünülebilir. erkek adayların sayısının çoğunlukta olduğu çalışmaların olduğu gibi (Sağer, Zahal ve Gürpınar, 2013; Sağer ve diğerleri, 2014) kız adayların sayısının yoğunlukta olduğu çalışmalar da mevcuttur (Ece ve Kaplan, 2008; Sungurtekin, 2006). Araştırma bulgusuyla paralel bir şekilde mezun olunan lise türüne göre GSSL ve genel lise mezunu aday sayısının, diğer liselerden mezun olan aday sayısından fazla olduğu birçok çalışmaya rastlanmaktadır (Ece ve Kaplan, 2008; Öztürk, 2008; Sağer ve diğerleri, 2013; Sağer ve diğerleri 2014; Sungurtekin, 2006).

Aşağıda Sosyo-demografik nitelikte olan bağımsız değişkenlerin sırasına göre, üç puan türündeki (Müziksel İşitme-Yazma (MIY) Alanı, Müziksel Çalma Alanı ve Müziksel Söyleme Alanı) anlamlı farklılık durumları verilmiştir.

- Cinsiyete göre üç puan türünde de anlamlı farklılık bulunmamıştır.

Ece ve Kaplan'ın (2008) çalışmasında, adayların cinsiyetlerine göre Müziksel İşitme Alanı puanlarında anlamlı farklılık olmadığı bulunmuştur. Bu bulgu yapılan araştırma ile benzerlik göstermektedir. Buna karşın, Müziksel Söyleme ve Müziksel Çalma Alanı puanlarında erkek öğrencilerin lehine anlamlı farklılık olduğu saptanmıştır. Sağer ve diğerleri (2014) tarafından yapılan çalı̧̧mada ise cinsiyete göre MIY puanlarında ve Müziksel Çalma Alanı puanlarında anlamlı farklılık olmadığı; Müziksel Söyleme Alanı puanlarında kız adayların lehine anlamlı farklılıklar olduğu tespit edilmiştir.

- Mezun olunan lise türüne göre, Müziksel Söyleme Alanı puanları dışındaki diğer puan türlerinde anlamlı farklılık olduğu sonucu 
bulunmuştur. Bu farklılığın her iki puan türünde de GSSL mezunu adayların puanlarının lehine olduğu tespit edilmiştir. GSSL mezunu adayların puanlarının; genel lise ve diğer lise türlerinden mezun olan adayların puanlarına göre anlamlı farklılık gösterdiği ve GSSL mezunu adayların MiY Alanı puanlarının ve Müziksel Çalma Alanı puanlarının daha yüksek olduğu saptanmıştır.

Ece ve Kaplan'ın (2008) çalışmasında adayların Müziksel İşitme Alanı puanlarında ve Müziksel Çalma Alanı puanlarında mezun oldukları lise türüne göre GSSL mezunu adayların lehine anlamlı farklılık olduğu bulunurken; Müziksel Söyleme Alanı puanlarında bu değişkene göre anlamlı farklılık olmadığı saptanmıştır. Bu bulgu yapılan araştırmada ulaşılan sonuçlarla paralellik göstermektedir. Sağer ve diğerlerinin ( 2014) araştırmasında ise lise türüne göre 3 puan türünde de GSSL mezunu adayların lehine anlamlı farklılık olduğu ve bu gruptakilerin daha başarılı olduğu sonucuna ulaşılmıştır. MIY Alanı puanları ve Müziksel Çalma Alanı puanlarındaki bu farklılaşma durumu araştırma sonuçları ile benzerlik göstermektedir. Öztürk (2008) tarafından yapılan çalışmada ise araştırma bulgusunu destekler nitelikte sınava, müzik alanı mezunu olarak başvuranların; Müziksel OkumaYazma ve Müziksel Çalma Alanlarında daha yüksek puanlar aldığı tespit edilmiştir.

- Yaşantının çoğunun geçirildiği yere göre, MIY Alanında anlamlı farklılık bulunmuş; Müziksel Çalma Alanı ve Müziksel Söyleme Alanı puanlarında anlamlı farklılık bulunmamıştır. Yaşantısının çoğunu büyükşehirde geçiren adayların MIY Alanı puanlarının; ilçe ve kasabaköy'de geçiren adaylara göre anlamlı farklılık gösterdiği tespit edilmiştir.

Sağer ve diğerleri (2014) tarafından yapılan çalışmada ise yaşantının çoğunun geçirildiği yere göre MIY ve Müziksel Söyleme puanlarında farklılık bulunmadığı; yaşantıların önemli bir kısmını büyükşehir ve illerde geçiren adayların Müziksel Çalma Alanı puanlarının köy-kasaba grubundakilere göre anlamlı farklılık gösterdiği ve bu gruptakilerin daha başarılı oldukları tespit edilmiştir.

- Yaşantının çoğunun geçirildiği bölgeye göre üç puan türünde de anlamlı farklılık bulunmamıştır.

- Aile müzik ilgi durumuna ve aile aylık gelir durumuna göre, üç puan türünde de anlamlı farklılık bulunmamıştır.

Sağer ve diğerlerinin (2014) araştırmasında aile aylık gelir durumuna göre Müziksel Çalma Alanı puanlarında anlamlı farklılık bulunmazken; MIY puanlarının, 2000-2999 grubundakilerin 0-999 grubundakilere göre; Müziksel Söyleme Alanı puanlarının 3999 grubundakilerin ise 2000-2999 grubundakilere göre daha yüksek olduğu ve anlamlı farklılık gösterdiği tespit edilmiştir.

- Özel yetenek sınavlarına hazırlık süresine göre, MiY Alanı ve Müziksel Çalma Alanı puanlarında anlamlı farklılık bulunmuş; Müziksel Söyleme Alanı puanlarında anlamlı farklılık bulunmamıştır. Hazırlık süresine göre 4 yıl 1 gün-5 yıl ve 5 yıldan fazla hazırlananların MIY Alanında; 4 yıl 1 gün-5 yıl arasındaki sürelerde hazırlananların Müziksel Çalma Alanında daha yüksek puanlar aldıkları tespit edilmiştir.

- Özel yetenek sinavlarina hazırlanma biçimlerine göre, Müziksel Söyleme Alanı puanları dışındaki diğer puan türlerinde anlamlı farklılık olduğu sonucuna ulaşılmıştır. GSSL'lerde aldıkları eğitimle sinavlara hazırlanan adayların Müziksel Çalma Alanı puanlarının; dershane ve kurslarda hazırlanan adayların puanlarına göre daha yüksek olduğu ve farkların anlamlı olduğu saptanmıştır. GSSL'lerde aldıkları eğitimle sinavlara hazırlanan adayların; özel-bireysel ders alanlardan, dershane-kurslara gidenlerden ve kendi çabası ile bireysel olarak hazırlananlardan MIY alanında daha başarılı oldukları ve farkların anlamlı olduğu bulunmuştur. Ayrıca dershane ve kurslara giden adayların, özel-bireysel ders alan adaylara göre MIY Alanı puanlarının daha yüksek olduğu ve farkın anlamlı olduğu saptanmıştır. 
- Okul ve özel yetenek sinavlarına hazırlık süreci dişında müzik eğitimi alma durumuna göre, MIY Alanı puanlarında anlamlı farklılık bulunmuş, diğer puan türlerinde ise anlamlı farklılık bulunmamıştır. Okul ve sınavlara hazırlık süreci dışında müzik eğitimi almayanların; halkeğitim merkezlerinde müzik eğitimi alanlardan ve özel-bireysel ders alanlardan MiY alanında daha başarılı oldukları ve farkların anlamlı olduğu tespit edilmiştir. Aynı zamanda dershane ve kurslarda müzik eğitimi alanlar ile özel-bireysel ders alanlar ve halk eğitim merkezlerinde müzik eğitimi alanlar arasında anlamlı farklılıklar olduğu; dershane ve kurslarda müzik eğitimi alanların MIYY alanı puanlarında daha başarılı oldukları saptanmıştır.

- Çalg1 alanına göre, MIY Alanı puanlarında anlamlı farklılık bulunmuş; Müziksel Çalma Alanı ve Müziksel Söyleme Alanı puanlarında anlamlı farklılık bulunmamıştır. Sınava en fazla katılımın olduğu dört gruba (keman, piyano, bağlama, klasik gitar) bakıldığında, MIY Alanında en başarılı iki grubun piyano ve keman alanında performans gösterenler olduğu saptanmıştır. Aynı zamanda flüt ve viyolonsel alanında performans gösteren adayların da MIY Alanında yüksek puanlar aldıkları tespit edilmiştir. Blokflüt alanında performans gösteren adayların, MIY Alanı puanları açısından en düşük grup olduğu tespit edilmiştir.

Piyano ve keman alanında performans gösteren adayların; klasik gitar, bağlama ve viyolonsel alanında performans gösteren adaylardan MIY Alanı puanlarının daha yüksek olduğu ve farkların anlamlı olduğu bulunmuştur. Çalgı alanı klasik gitar olanların; piyano, keman, flüt ve viyolonsel olan adaylardan MIY alanında daha başarısız oldukları, blokflüt olanlardan ise daha başarılı oldukları ve farkların anlamlı olduğu saptanmıştır. Çalgı alanı flüt olan adayların, MİY Alanı puanlarının; bağlama, blokflüt ve klasik gitar olan adaylardan daha yüksek olduğu ve farkların anlamlı olduğu bulunmuştur. Çalgı alanı bağlama olan adayların; piyano, keman, flüt ve viyolonsel olan adaylardan Mi̇Y Alanı puanlarının daha düşük; blokflüt olanlardan ise daha yüksek olduğu ve farkların anlamlı olduğu tespit edilmiştir. Çalgı alanı viyola olanların; blokflüt olan adaylara göre MIY Alanında daha başarılı oldukları, viyolonsel olan adaylara göre ise daha başarısız oldukları ve farkların anlamlı olduğu saptanmıştır.

$\mathrm{Bu}$ bulgular 1şığında aşağıdaki önerilerde bulunulmuştur.

Müzik Öğretmenliği Programı seçme sınavlarındaki müzik alanına yönelik alt testler ve bu alt testlerin adayların sosyo-demografik, müziksel yaşantı-hazırlık vb. özelliklerine ilişkin değişkenlere göre farklılaşma durumları konusunda yeterli çalışma olmadığı saptanmıştır. Müzik araştırmacılarının bu konu üzerinde çalışmalar yapması gerekmektedir.

Özel yetenek sinavları ile ilgili literatür incelendiğinde, öğrenci kaynağının sadece lise türü ve cinsiyet açısından ele alındığı sınırlı sayıda çalışma olduğu görülmektedir. Öğrencilerin tanınması ve bu doğrultuda eğitimöğretim faaliyetlerinin belirlenmesi açısından öğrencilerin çeşitli sosyo-demografik açılardan başarı durumlarının incelendiği araştırma sayısı arttırılmalıdır.

Araştırma kapsamında ele alınan sınavda, adayların sosyo-demografik özelliklene göre diğer puan türlerinde anlamlı ilişki çıkmasına rağmen Müziksel Söyleme alanı puanlarında böyle bir ilişkinin olmaması dikkat çekicidir. Müziksel Söyleme alanına yönelik uygulamaların yeniden yapılandırılması gerekir.

Müziksel Çalma ve Müziksel Söyleme alanlarına ilişkin performans değerlendirme ölçekleri kullanılmalı, adayların bu alanlarındaki performanslarının değerlendirilmesinde kullanılan ölçütler titizlikle oluşturulmalıdır.

Eğer bu sinavlarda müziksel bilgi ve beceri kapsam dışında tutularak, amaç sadece müziksel yeteneğin ölçülmesi olacaksa; dikte, deşifre, çalma, söyleme gibi alanların uygulanmaması, bu alanların yerine ses, ritim, ezgi gibi alanlarda ayrım ve yineleme davranışlarını yapabilmeye ilişkin testlerin getirilmesi önerilmektedir. 
Eğer bu sinavlarda birçok üniversitede uygulandığı gibi ön bilgi gerektiren alanlar da ölçülecekse, deşifre uygulamalarının sadece solfej alanında değil, Müziksel Çalma ve Müziksel Söyleme alanlarında da yapılabileceği düşünülmektedir. Temel Müzik Teorisi, Müzik Tarihi ve Kültürü alanları konusunda da testler yapılarak sınav kapsamı genişletilebilir. $\mathrm{Bu}$ programların birincil amacının müzik öğretmeni yetiştirmek olduğu düşünüldüğünde, bu amaca yönelik olarak, adayların öğretmenlik yapabilme konusundaki hazırbulunuşluk düzeyinin ölçüleceği çoktan seçmeli kısa testler uygulanabilir.

\section{Kaynakça}

Atak Yayla, A. (2003). Müziksel Yeteneğin Ölçümü. Yayımlanmamış Doktora Tezi, Gazi Üniversitesi Eğitim Bilimleri Enstitüsü, Ankara.

Bentley, A. (1966). Musical Ability In Children and Its Measurement. London: Georg G. Harrap.

Boyle, J. David and Radocy, Rudolf E. (1987). Measurement and Evaluation of Musical Experiences. New York: Schirmer Books.

Büyüköztürk, Ş. (2007). Sosyal Bilimler İçin Veri Analizi El Kitabı. (7. Basım). Ankara: Pegem Akademi Yayıncilik.

Büyüköztürk, Ş., Çoklu Bökeoğlu, Ö., Köklü, N. (2009). Sosyal Bilimler İçin İstatistik. Ankara: Pegem Akademi Yayıncilık.

Colwell, R. (1970). The Evaluation of Music Teaching and Learning., C. Leonhard (Ed.), Prentice-Hall Contemporary Perspectives in Music Education Series. Englewood Cliffs, New Jersey: Prentice-Hall.

Cooper Cutting, J. (April, 2010). SPSS: Descriptive Statistics. [İnternet - 10.03.2011] : http://psychology.illinoisstate.edu/jccutti

Ece, A. S. ve Kaplan S. (2008). Müziksel Algılama (İşitme, Okuma, Yazma) Ses ve Çalgı Yeteneği Arasındaki İlişkilerin Farklı Değişkenler Açısından İncelenmesi. Kastamonu Eğitim Dergisi, 16(1), 285-296.

Gordon, Edwin E. (1979,1986). Primary Measures of Music Audiation (Kindergarten-Grade 3) and the Intermediate Measures of Music Audiation (Grade 1-Grade 6). Chicago: G.I.A. Publications.

İnönü Üniversitesi. (2010). Eğitim Fakültesi Güzel Sanatlar Eğitimi Bölümü Müzik Öğretmenliği Programı 2010-2011 Eğitim-Öğretim Yılı Ön Kayıt ve Yetenek Sinavları Kılavuzu.

Karasar, N. (2007). Bilimsel Araştırma Yöntemi. (17. Basım). Ankara: Nobel Yayın Dağıtım.

Kuzgun, Y. (2003). Meslek Rehberlĭği ve Danışmanlı̆̆ına Giriş. Ankara: Nobel Yayın Dağıtım.

Kwalwasser, J. (1927). Tests and Measurements in Music. Boston-New York: C. C. Birchard and Company.

Moos, J. Corrodi. (July, 1933). Some Recent Developments in Music Testing. The Musical Quarterly, Vol. 19, No. 3, 318-330. Web: http://www.jstor.org/stable/739080 adresinden 14 Şubat 2011 tarihinde alınmıştır.

Öztürk, Serkan. (2008). Müzik Öğretmenliği Programları Özel Yetenek Sınav Sonuçlarının Öğrenci Kaynakları Düzleminde İncelenmesi. Yayımlanmamış Yüksek Lisans Tezi, Gazi Üniversitesi Eğitim Bilimleri Enstitüsü, Ankara.

Roby, A. Richard. (Autumn, 1962). A Study in the Correlation of Music Theory Grades with the Seashore Measures of Musical Talents and the Aliferis Music Achievement Test. Journal of Research in Music Education, Vol. 10, No. 2, 137-142. Web: http://www.jstor.org/stable/3343997 adresinden 22 Mart 2011 tarihinde alınmıştır. 
Sağer, T., Zahal, O. ve Gürpinar, E. (2013). Müzik Öğretmenliği Programi Özel Yetenek Sınavlarında YGS Puanları ile Müzik Alanı Puanları Arasındaki İlişkilerin İncelenmesi. International Journal of Human Sciences. 10(1), 541-554.

Sağer, T., Zahal, O. ve Gürpinar, E. (2014). Müzik Öğretmenliği Programi Özel Yetenek Sınavlarına Giren Adayların, Alan Puanları ve Sınav Başarı Durumlarının Çeşitli Değişkenlere Göre İncelenmesi. Akademik Bakış Dergisi, (41)

Seashore, C. (1915). The Measurement of Musical Talent. New York: Schirmer Books.

Sungurtekin, M. (2006). U. Ü. Eğitim Fakültesi Güzel Sanatlar Eğitimi Bölümü Müzik Eğitimi Anabilim Dalı 2004-2005 Yetenek Sınavının Genel Değerlendirmesi. Uludağ Üniversitesi Eğitim Fakültesi Dergisi, 19(2), 399-414.

Togerson, T. L. and Fahnestock. (1926). Togerson-Fahnestock Music Test. Illinois. Bloomington: Public School Company.

Warnick, Edward M. (April, 1985). Overcoming Measurement and Evaluation Phobia. Music Educators Journal, Vol. 71, No. 8, 32-40. Web: http://www.jstor.org/stable/3396496?seq=7 adresinden 6 Şubat 2011 tarihinde alınmıştır.

Wing, H. (1970). Tests of Musical Ability and Appreciation (An Investigation Into the Measurement, Distribution, and Development of Musical Capacity). (Second Edition). London: Cambridge University Press.

Woodruff, C. Louis. (1983). A Predictive Validity Study of the Primary Measures of Music Audiation. Unpublished doctor's thesis, Temple University, America. 


\section{EXTENDED SUMMARY}

In Turkey, student selection for various higher education programmes of music education is via special talent exams. From residents of bigger cities to town and village people, graduates of various high schools with different family backgrounds from all corners of Turkey, enter these exams which were held particularly during the summer. Therefore, socio-demographic traits of these entrants differ greatly. These exams were applied according to the instructions prepared for the special talent exams by related departments and regulations determined by the regulations stated in OSYS guidelines. Although the scope of these exams may differ according to the musical behaviors to be measured, they still have similarities in terms of basic structure and the types of subtests. The musical dimension of the skill testwhich was examined within the scope of the study and used in the special talent exams in İnönü University, department of fine arts ,music education programme within the academic year of 2010-2011had three sections. These sections consisted of: field of musical hearing and writing (dictation, hearing 2, 3 and 4 note chords), field of singing (performance of a song or a classical work) and field of playing (instrumental performance) The examinaton had two phases: The first part- field of musial hearing and writing and the second part -fields of singing and instrumental performance (İnonu, 2010).

Given the fact that, the main source for these exams are the students, examination of the sociodemographic traits of the applicants of those music education programmes using special talent exams for the selection plays an important part in improving the quality of the education given in these institutions.

The possible existence of a relationship between entrants' music field scores and their personal backgrounds is an important point needs to be emphasized. Therefore, the nature of the relationship between the entrants' music field scores and their socio-demographic traits was considered as the main problem of this study.

In this direction, the problem situation shows itself as follows: What level of relationship exists between the entrants' special talent examination field scores and their socio-demographic traits?

In this study, the relationship status between music field scores and socio-demographic traits was examined. With the aim of detecting the entrants' socio- demographic traits problems and their music field scores, the sub problems of this study were structured as follows:

-What are the frequency and percentage distributions of the entrants of special talent exams in terms of the independent variables of gender, age, type of high school they graduated from, the region the entrants has spent most of their lives, parents' educational levels, families' monthly income?

In terms of various independent variables, do entrants of special talent exams show any significant difference in the field scores of: Musical hearing-writing, instrumental performance, singing-according to various variables?

This study is thought to be of importance in describing the current states of the entrants within the fields of musical hearing- writing, singing and instrumental performance and in giving opinons about the relationship between their special talent exam field scores and socio-demographic traits. It is expected to be useful in enlightening music educators, candidate students and their families, researchers and other related institutions and in supporting the studies that would follow.

The population of this study -which was conducted by using the survey method- consisted of 387 entrants for the special talents examination of Inönü University, Department of Fine Arts, Music Education Programme

Data collecting tools comprised of a "Personal Information Form" and their "exam scores". Entrants' special talent exam scores were obtained from the related unit of the deanery of the faculty of education. (İnönü Üniversitesi, 2010). For analysis, all data were processed by using statistical analysis software SPSS version 16.0. Firstly, the statistics related to the traits of the entrants in the study group were presented by giving their frequency and percentage values. Within the second phase, their Skewness and Kurtosis values were calculated and Kolmogorow-Smirnov tests were applied. For the groups having no normal distribution according to the sub-questions of the study $(n<30)$, Mann-Whitney U Test and Kruskal-Wallis $\mathrm{H}$ test; for the groups with normal distribution $(n>30)$, t-test, one way analysis (ANOVA) and Tukey test were used. 
Considering the findings related to the distribution of entrants' socio-demographic variables; the results show that: Male entrants outnumber the female and the density in terms of age was between 17-20; Graduates of high schools of fine arts and sports and public high schools comprises the majority in terms of the type of high school the entrants graduated from; the majority of the entrants live in cities and metropolises in terms of the place they have spent most of their lives; The number of the entrants from the eastern anatolian region were higher than the rest in terms of the region entrants have spent most of their lives. In terms of the educational level of mother,the number of the entrants whose mothers graduated from primary school or high school graduates and in terms of the educational level of father the number of the entrants with fathers graduated from primary school or high school comprise the majority, the accumulation is 550-1499 TL (Turkish Liras) in terms of the families' monthly income.

Significant differences in three different types of scores-field of musical hearing-writing, field of Instrumental performance and field of singing- are presented as follows:

- In terms of gender, three score types showed no difference.

- In terms of the school type the entrants graduated from, two score types -except singing- showed significant difference. In these two score types, this difference was detected to be on behalf of the scores of the high school of fine arts and sports graduates.

- In terms of the place the entrants has spent most of their lives, unlike the two other fields, field of musical hearing and writing showed significant difference. This difference was mostly associated with the entrants spent most of their lives in towns and villages.

- Three score types showed no significant difference in terms of the region the entrants have spent most of their lives.

- Three score types showed no significant difference in terms of families' level of interest in music and their monthly income.

- Field of musical hearing an writing and instrumental performance scores showed significant difference in terms of the time entrants spent to prepare for the special talent exam. entrants prepared for a time period of 4 years and a day- 5 years scored higher in the fields of musical hearing and writing and instrumental performance.

Two fields except the field of musical hearing and writing showed significant difference in terms of in terms of the way the entrants prepare for the special talent exam. Entrants prepared by using their high school of fine arts and sports backgrounds scored significantly higher than the entrants prepared by assigning a private course.

- Unlike the two other fields; field of musical hearing and writing showed significant difference in terms of entrants' previous music background aside from the school or the exam preparation. Entrants who didn't have any background aside from the school and exam preparation scored significantly higher than the entrants who received music education in the institutions of public education and through private tuition.

- Unlike the other two fields, field of musical hearing and writing showed significant difference in terms of the instrument played. When the four mostly participated groups (the violin, the piano, the baglama and the classical guitar) are considered, it was found out that the two groups with the most success were the piano and the violin. Also, players of the flute and the cello scored high in the field of musical hearing and writing. Players of the recorder had the lowest scores in terms of field of musical hearing and writing. 